\title{
WestVirginiaUniversity
}

THE RESEARCH REPOSITORY @ WVU

Graduate Theses, Dissertations, and Problem Reports

2010

\section{Extraction of metal sensitizers under physiologically relevant conditions}

\author{
Matthew G. Duling \\ West Virginia University
}

Follow this and additional works at: https://researchrepository.wvu.edu/etd

\section{Recommended Citation}

Duling, Matthew G., "Extraction of metal sensitizers under physiologically relevant conditions" (2010). Graduate Theses, Dissertations, and Problem Reports. 4583.

https://researchrepository.wvu.edu/etd/4583

This Thesis is protected by copyright and/or related rights. It has been brought to you by the The Research Repository @ WVU with permission from the rights-holder(s). You are free to use this Thesis in any way that is permitted by the copyright and related rights legislation that applies to your use. For other uses you must obtain permission from the rights-holder(s) directly, unless additional rights are indicated by a Creative Commons license in the record and/ or on the work itself. This Thesis has been accepted for inclusion in WVU Graduate Theses, Dissertations, and Problem Reports collection by an authorized administrator of The Research Repository @ WVU. For more information, please contact researchrepository@mail.wvu.edu. 
Extraction of Metal Sensitizers Under Physiologically Relevant Conditions

\author{
Matthew G. Duling \\ Thesis submitted to the \\ College of Engineering and Mineral Resources \\ at West Virginia University in partial fulfillment of the requirements \\ for the degree of Master of Science in Industrial Hygiene
}

Steve Guffey, Ph.D., Chair

Warren Myers, Ph.D.

Christopher Coffey, Ph.D.

Department of Industrial and Management Systems Engineering

Morgantown, West Virginia 2010

Keywords: Bioassessibility; Dissolution; Simulated Sweat

Copyright 2010 Matthew Duling 


\begin{abstract}
Extraction of Metal Sensitizers Under Physiologically Relevant Conditions
\end{abstract}

\author{
Matthew G. Duling
}

Metal and metal alloys are critical components of high-tech applications. Beryllium (Be), chromium ( $\mathrm{Cr}$ ), and nickel ( $\mathrm{Ni}$ ) are among the most economically important metals for high-tech applications because of their extraordinary physical properties. These metals pose two different problems for workers who work with them: 1) allergic contact dermatitis from exposure to $\mathrm{Cr}$ and $\mathrm{Ni}$, which is widely accepted to account for a significant percentage of occupational skin irritations and 2) possible systemic sensitization from skin contact with airborne Be. Proper assessment of skin contact with allergenic metals during work is difficult. Current practices for the assessment of skin exposure are to either remove a sample of material from the skin surface or to intercept a sample of the material using a substrate such as cotton gloves or cloth patches. Upon collection, the metal content of the sample is dissolved completely using strong acids, followed by analysis using atomic spectroscopy. While this analytical approach is chemically valid (i.e., nitric acid and hydrochloric acid to dissolve beryllium, (NMAM 7303), a major shortcoming of this approach is that the masses of metals are reported without consideration of the bioaccessible (i.e., available for absorption) form and mass. The bioaccessible (water-soluble) form of these metals is of utmost concern because it is the form that can be readily absorbed through the upper layer of the skin and into the immunologicallyactive layer of the epidermis. This study investigated the extraction of bioaccessible forms of $\mathrm{Be}, \mathrm{Cr}$, and $\mathrm{NI}$ under physiologically relevant conditions as an alternative to acid-assisted digestion procedures in current use. Simulated human sweat was used to extract and quantify $\mathrm{Be}, \mathrm{Cr}$, and $\mathrm{Ni}$ metals in their bioaccessible forms. Specifically, this study evaluated the influence of simulated sweat contact time and skin temperature on the dissolution of $\mathrm{Be}, \mathrm{Cr}$, and Ni powders. Results from this study will be used to define the optimal simulated human sweat conditions for the dissolution of metal sensitizers into their bioaccessible forms for exposure assessment. 


\section{Table of Contents}

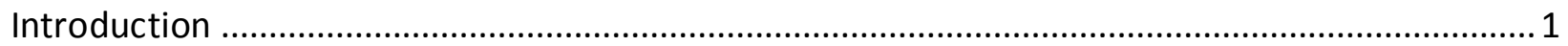

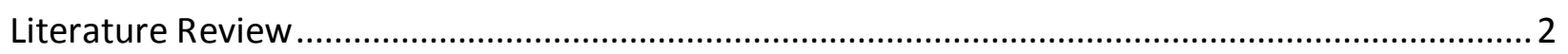

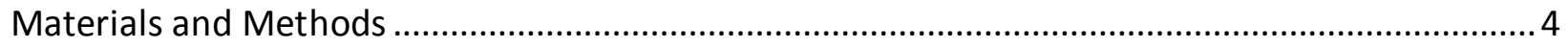

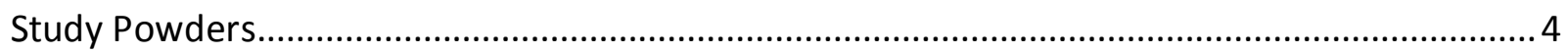

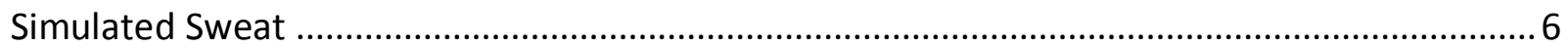

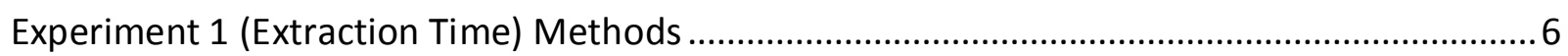

Experiment 2 (Effects of Temperature on Bioaccessibility) Methods.......................................... 8

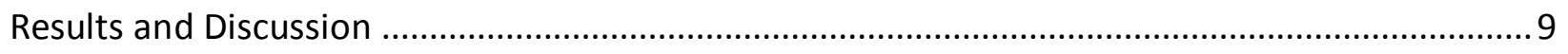

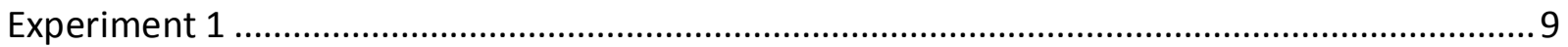

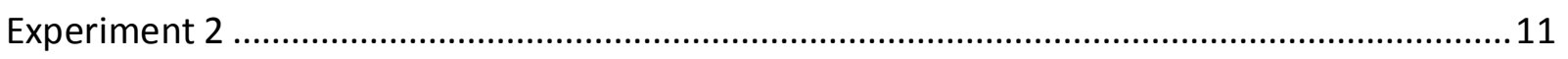

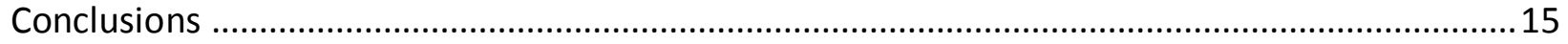

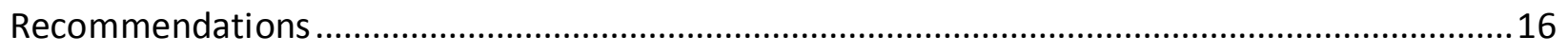

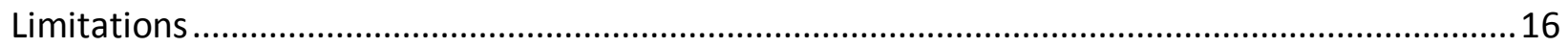

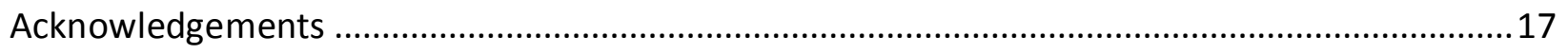

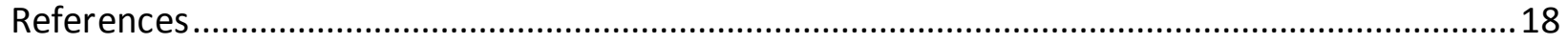

Appendix I. Statistical Derivation of Dissolution Equation ..........................................................21

Appendix II. (Excerpted and amended from Simulated Human Sweat Protocol, Stefaniak and

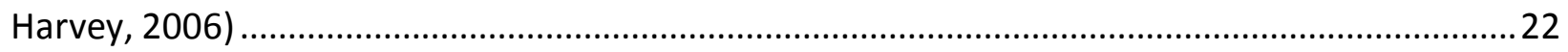

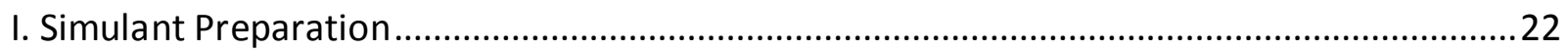

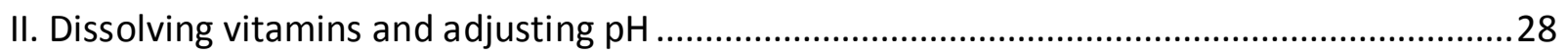

Appendix III. (Excerpted and amended from Dissolution of Beryllium Compounds in Artificial

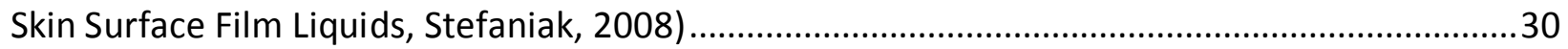

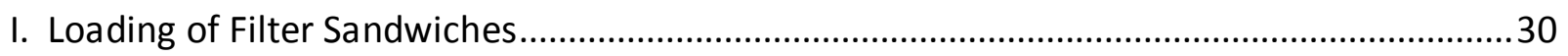

II. Experimental Set up, Monitoring, and Sample Collection ........................................................30

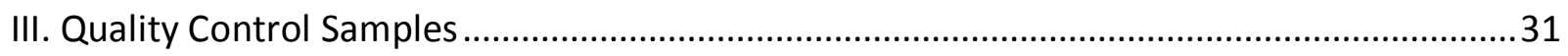

Appendix IV. Data Tables from SAS Analysis....................................................................................33 


\section{Introduction}

Metal and metal alloys are critical components of high-tech applications. Beryllium (Be), chromium ( $\mathrm{Cr}$ ), and nickel ( $\mathrm{Ni}$ ) are among the most economically important metals for high-tech applications because of their extraordinary physical properties. For example, Be metal is light, highly machinable, and quickly dissipates heat, making it useful in applications such as military jet navigation and brake systems and aerospace (e.g., space craft structural members). Chromium and nickel, because of their electronegativities, are used to passivate the stainless steel and metal alloys used in biomedical applications. These metals pose two different problems for workers who work with them: 1) allergic contact dermatitis from exposure to $\mathrm{Cr}$ and $\mathrm{Ni}$, which is widely accepted to account for a significant percentage of occupational skin irritations and 2) systemic sensitization from skin contact with airborne Be, which upon subsequent inhalation exposure and development of a lung burden may lead to chronic beryllium disease (Day et al., 2006). Given the allergic nature of these responses, it is prudent for workers to avoid skin contact with these metals thereby minimizing the opportunity for developing or eliciting an immune reaction.

Proper assessment of skin contact with allergenic metals during work is difficult. Current practices for the assessment of skin exposure are to either remove a sample of material from the skin surface or to intercept a sample of the material using a substrate such as cotton gloves or cloth patches. Upon collection, the metal content of the sample is dissolved completely using strong acids, followed by analysis using atomic spectroscopy. While this analytical approach is chemically valid (i.e., nitric acid and hydrochloric acid to dissolve beryllium, (NMAM 7303), a major shortcoming of this approach is that the masses of metals are reported without consideration of the bioaccessible (i.e., available for absorption) form and mass. The bioaccessible (water-soluble) form of these metals is of utmost concern because it is the form that can be readily absorbed through the upper layer of the skin and into the immunologicallyactive layer of the epidermis.

This study investigated the extraction of bioaccessible forms of $\mathrm{Be}, \mathrm{Cr}$, and $\mathrm{NI}$ under physiologically relevant conditions as an alternative to acid-assisted digestion procedures in current use. Simulated human sweat was used to extract and quantify $\mathrm{Be}, \mathrm{Cr}$, and Ni metals in their bioaccessible forms. Specifically, this study evaluated the influence of simulated sweat contact time and skin temperature on the dissolution of $\mathrm{Be}, \mathrm{Cr}$, and Ni powders. Results from this study will be used to define the optimal simulated human sweat conditions for the dissolution of metal sensitizers into their bioaccessible forms for exposure assessment. Time and $\mathrm{pH}$ data will aid in understanding the variability in human responses to skin contact with 
metal sensitizers and to inform efforts to identify optimal conditions for future bioaccessibility studies.

\section{Literature Review}

An exhaustive literature search returned many published documents that discuss bioaccessibility and several that investigate bioavailability of metals in the gastrointestinal tract and across cadaver or surgical waste skin. However, few articles pertaining to the dissolution of hard metal sensitizers into a bioaccessible state were found. The articles below detail the studies conducted and the relevant physiological skin conditions.

Understanding how metal sensitizers respond to contact with human skin important when assessing actual exposures. Bioaccessibility is the ability of a substance to traverse the skin barrier. For metal sensitizers, water-soluble valence states represent the bioaccessible form (Forte et al., 2008). Both soluble and insoluble forms of Be (Curtis, 1951; Zissu et al., 1996; Tinkle et al. 2003), Cr (Chiba et al., 1997; Hansen et al., 2003; Van Lierde et al., 2006), and Ni (Covington et al., 1985; Fullerton et al., 1986; Hemingway and Molokhia, 1987; Ikarshi et al., 1992; Haudrechy et al., 1993; Tanojo et al., 2001; Fournier and Govers, 2003; Larese-Filon et al., 2004; Larese et al., 2007) may dissolve and penetrate skin to induce sensitization.

The possible contribution of skin exposure to beryllium sensitization has been recognized for 50 years. Curtis (1951) reported that soluble salts, such as the beryllium fluoride and beryllium sulfate contained in dust that had settled onto the exposed skin. The particles on the face, neck and upper extremities, were quickly dissolved by sweat. This resulted in dermatitis, ostensibly caused by ionic beryllium (Day et al. 2006).

At present there is limited data on nickel release from small nickel particles in simulated sweat (Midander, 2007). Midander investigated the bioaccessibility of Ni in the EN1811 formula, $(0.5$ wt\% sodium chloride, $0.1 \mathrm{wt} \%$ lactic acid, $0.1 \mathrm{wt} \%$ urea and normal ultrapure water, (not aerated as described in the standard), the $\mathrm{pH}$ of the solution was adjusted to $6.5 \mathrm{using} 0.1 \mathrm{wt} \%$ ammonia solution. The samples of Ni powder and $7.5 \mathrm{~mL}$ of sweat were then incubated at $30^{\circ} \mathrm{C}$ for the 5 different time durations, $(0.5,1,4,8,12 \mathrm{hrs})$. Midander found that $\mathrm{Ni}$ had reached a steady state of dissolution for the lower masses, $\left(0.1,0.5,1,3 \mathrm{mg} / \mathrm{cm}^{2}\right)$. However, steady-state was not reached for the $5 \mathrm{mg} / \mathrm{cm}^{2}$ sample. Conversely, Midander did not represent known physiological conditions in the study.

The data support that under the influence of human sweat, pure cobalt, nickel and chromium will release metal ions that may cause allergic contact dermatitis (Julander, 2009). Julander examined the dissolution of metal discs in sweat formula EN1811 at the time points 2-minutes, 1-hour, 1-day, and 1-week. The 1-day and 1-week exposure times seem too long to be relevant 
to an occupational setting. Julander also used $30^{\circ} \mathrm{C}$ and $\mathrm{pH} 6.5$ as the simulated physiological conditions which do not represent the mean skin surface environment. Cobalt, nickel and chromium were released by all discs $(n=7)$ at concentrations that increased with time in the simulated sweat. Among healthy adults, skin pH is 4.2 to 6.1 (Agache, 2004a), with median of $\mathrm{pH} 5.3$ (Stefaniak and Harvey, 2006). On the skin surface, temperature varies from 33 to $45^{\circ} \mathrm{C}$, depending upon the anatomical site, with a median whole-body temperature of $36^{\circ} \mathrm{C}$ (Stefaniak and Harvey, 2006). Note that the anatomical regions of interest for this study (finger tips, palms) have temperatures near $33^{\circ} \mathrm{C}$ (Agache, 2004), which is lower than the median whole-body value.

It is postulated that under physiologically relevant conditions metals may ionize and so permeate the skin (Larese/Filon, 2004, 2007, 2009). Filon used a Franz cell system in all of her studies to assess the skin permeability of metal ions dissolved in simulated sweat. The formula of sweat used was similar to the EN1811 formula. All studies were performed at $32^{\circ} \mathrm{C}$ to approximate the temperature of the human hand. Permeation of the metals across a skin membrane was measured by removing aliquots of $1.5 \mathrm{~mL}$ of the sweat solution from the sample cup at the ends of hours $2,4,8,16,18,20,22$, and 24 . The initial time points of the study represent typical occupational exposure situations. However, a 10-hour study is more representative of the duration of time that contaminants may contact skin (Day et al., 2009). Filon found that nickel dissolved in the sweat formula she used, but chromium did not. Research using a more physiologically relevant formula of simulated sweat could return different results.

The current practice for analysis of dermal exposure samples containing metal sensitizers is to digest in strong acid and high heat. However, that analysis provides no insight into the fraction of the sample that could dissolve into a form capable of crossing the human skin barrier. This 'bioaccessible' form of the metal sensitizer is of paramount importance because that is the only soluble form capable of traversing the skin barrier. Furthermore the dissolution conditions of the human body are far from $\mathrm{pH} 1$ and $95^{\circ} \mathrm{C}$. Issues of bioaccessibility and bioavailability are not restricted to dermal exposure research. Extensive research has been done in the gastrointestinal (GI) environment to access the bodies' susceptibility to exposure to metals during ingestion. Bioaccessibility is greater than bioavailability for metals in both gastrointestinal compartments (Ellickson et al., 2001). Ellickson investigated the bioavailability of lead and arsenic by introducing the contaminants to synthetic analogues of human GI fluids. Both lead and arsenic were found to be soluble in the gastric fluids, and only the soluble fraction crossed the intestinal membranes into the blood and organs of the test animals. Dean and $\mathrm{Ma}$ (2007) reviewed a physiologically-based extraction test (PBET) as a tool in assessing the risk to humans from persistent organic pollutants (POPs) and metals. They sought to mimic the process of human food digestion and thereby more accurately assess the bioavailability of POPs 
and metals. They concluded that simulated gastrointestinal extraction provides important information for assessment of contaminated soil waste and other related materials and that future development requires the establishment of a standard protocol for the assessment of bioaccessibility.

Bioaccessibility and bioavailability research concepts have been used in the assessment of welding exposures to manganese and nickel. Berlinger et al. (2009) stated that during the first step of the extractions, $37^{\circ} \mathrm{C}$ was employed instead of $20^{\circ} \mathrm{C}$ (Thomassen et al., 2001) to create temperature conditions experienced in the human body, thereby obtaining more representative results. Some international standards for work-place air measurements, (e.g. ISO 1502:2000), also recommend the use of $37^{\circ} \mathrm{C}$ when the soluble fraction of metals is determined.

Understanding of occupational skin exposures to multiple metal sensitizers remains poor. There is little methodological guidance in terms of the assessment of such exposure, the combined toxicological mechanisms, or risk to health (Day, 2009).

This study investigated the optimal physiological conditions for dissolution of beryllium, chromium and nickel to their bioaccessible form in simulated human sweat. Specifically this research will address the gap in understanding of the optimum time and temperature conditions needed to properly assess the bioaccessible fraction of the contaminant. This fraction is important when assessing the dermal exposure of a worker because emerging evidence suggests that the skin is an important route of exposure that leads to respiratory disease upon subsequent inhalation exposures (Day et al., 2006; Bello et al., 2007; Redlich and Herrick, 2008).

\section{Materials and Methods}

All studies were performed at the NIOSH Laboratory in Morgantown, WV. All samples were analyzed by Bureau Veritas North America (BVNA) Laboratories in Novi, MI. BVNA is the contract analytical laboratory for NIOSH and all samples must be analyzed by them unless they are unable to complete the analysis.

\section{Study Powders}

The characteristics of the powers used are important when interpreting the results of the experiments. The bulk Be metal powder was sampled from a primary production facility (Hoover et al. 1989) found to have an elevated prevalence of sensitization (Kreiss et al., 1997). The bulk Chromium Carbide $\left(\mathrm{Cr}_{3} \mathrm{C}_{2}\right)$ and Ni powders were taken from containers of feedstock materials at a "hard metal" manufacturer (Stefaniak et al. 2007). The test powder particle sizes 
range from a mean diameter of 2.6-micrometer clusters of $\mathrm{Cr}_{3} \mathrm{C}_{2}$, to the 3.2-micrometer diameter particles of Be metal, to the 4.0-micrometer diameter clusters of Ni metal. Figure 1 summarizes all the characterization of the properties all of the test powders. These chemical properties of the powders were evaluated using powder X-ray diffraction (crystallinity) and Xray photoelectron spectroscopy (surface elements and bonding states). Physical properties of the particles were evaluated using scanning electron microscopy (morphology, particle size), helium pycnometry (density), and nitrogen gas absorption (surface area).
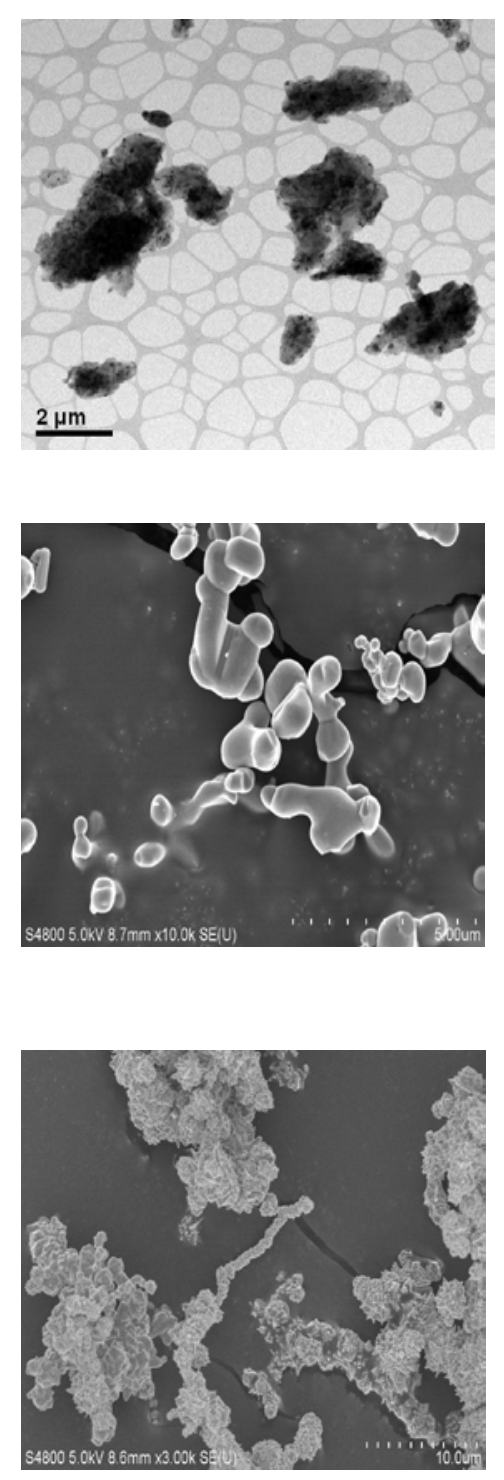

Beryllium metal

Surface chemistry $=\mathrm{BeO}, \mathrm{Be}$

Crystalline composition $=\mathrm{Be}$

Morphology = irregular shaped particles

Particle size, $\mu \mathrm{m}=3.2(1.8)^{\mathrm{a}}$

$\mathrm{SSA}, \mathrm{m}^{2} / \mathrm{g}=5.6 \pm 0.02$

Density, $\mathrm{g} / \mathrm{cm}^{3}=1.86 \pm 0.02$

Chromium carbide

Surface chemistry $=\mathrm{Cr}, \mathrm{CrC}_{3}, \mathrm{Cr}_{2} \mathrm{O}_{3}$

Crystalline composition $=\mathrm{CrC}_{3}$

Morphology $=$ fused cluster particles

Cluster size, $\mu \mathrm{m}=2.6$ (1.6)

$\mathrm{SSA}, \mathrm{m}^{2} / \mathrm{g}=1.04 \pm 0.02$

Density, $\mathrm{g} / \mathrm{cm}^{3}=6.97 \pm 0.19$

$\underline{\text { Nickel metal }}$

Surface chemistry $=\mathrm{Ni}_{2} \mathrm{O}_{3}, \mathrm{Ni}(\mathrm{OH})_{2}, \mathrm{NiO}$,

Crystalline composition $=\mathrm{Ni}$

Morphology $=$ clusters

Cluster size, $\mu \mathrm{m}=4.0$ (1.5)

$\mathrm{SSA}, \mathrm{m}^{2} / \mathrm{g}=7.04 \pm 0.18$

Density, g/ $/ \mathrm{cm}^{3}=9.46 \pm 0.29$

Figure 1. Physicochemical properties of study powders. ${ }^{a}$ Geometric mean (geometric standard deviation) 


\section{Simulated Sweat}

This study consisted of two experiments, (Extraction Time and Effects of Temperature on Bioaccessibility), both of which use a simulated sweat whose composition mimics human sweat constituents, concentrations, $\mathrm{pH}$, and temperature (Stefaniak and Harvey, 2006). The formula and procedures for the composition of the simulated sweat are described in Appendix I.

\section{Experiment 1 (Extraction Time) Methods}

The dissolution kinetics of $\mathrm{Be}, \mathrm{Cr}$, and $\mathrm{Ni}$ in simulated sweat were investigated to identify the most appropriate extraction time for each. A static dissolution technique (Stefaniak et al., 2005) was used for this experiment (Appendix II). Each individual sample chamber was loaded with about $5 \mathrm{mg}$ of the tested powder by constructing a filter "sandwich" with the tested powder between two Millipore Nitrocellulose $0.025 \mu \mathrm{m}$ filters held together by a dissolution chamber, (see Figure 2).

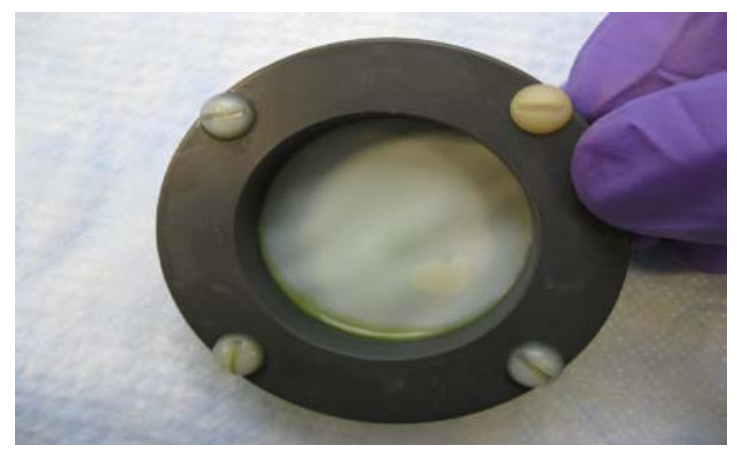

Figure 2. Dissolution Chamber

The chambers were then immersed in $80 \mathrm{~mL}$ of simulated human sweat (Stefaniak and Harvey, 2006) in a pre-sterilized sample cup $\left(T_{0}\right)$. The design of the chamber allows for free contact of the filter sandwich with the simulated sweat with only the outer few millimeters of the edge clamped in the chamber and thus unavailable. The solution was changed out at the time points designated in Table 1. These time-points were chosen in order to observe any changes in dissolution rate within the first few hours and to ensure sample that results would be above LOD. Between change-outs the sample chambers were incubated at $36^{\circ} \mathrm{C}$, the median temperature for human skin. The $\mathrm{Cr}$ and Ni samples were stabilized by adding $2 \mathrm{~mL}$ of $25 \%$ Nitric Acid before they were frozen at $-10^{\circ} \mathrm{C}$ to await analysis (Larese/Filon et al, 2004, 2007). Three samples of each powder were prepared for each experiment. The metal content of each sample was analyzed using NIOSH Manual of Analytical Methods (NMAM) 7303 Inductively Coupled Argon Plasma, Atomic Emission Spectroscopy, (ICP AES). 
Table 1. The time points and temperatures used for experiments 1 and 2 .

\begin{tabular}{|l|c|c|c|c|}
\hline \multicolumn{1}{|c|}{ Metal } & Mass (mg) & Time Points (Hour from $\mathbf{T}_{\mathbf{0}}$ ) & Sweat Temp $\left({ }^{\circ} \mathbf{C}\right)$ & Sweat $\mathbf{p H}$ \\
\hline Beryllium & $\approx 5$ & $1,2,3,4,5,7,9,11$ & $33,36,45$ & 5.3 \\
\hline Chromium & $\approx 5$ & $1,2,3,4,5,7,9,11$ & $33,36,45$ & 5.3 \\
\hline Nickel & $\approx 5$ & $1,2,3,4,5,7,9,11$ & $33,36,45$ & 5.3 \\
\hline
\end{tabular}

All statistical analyses were performed using SAS version 9.1 (Cary, North Carolina). For each experiment, the mass fractions of material remaining, $\left(M / M_{0}\right)$ were plotted versus time $(t)$. Either a single- or a multiple-component negative exponential function was fitted to the data by the SAS model (see Figure 3). Regression of values of time to values of $M / M_{0}$ is used to determine the slope with units of fraction/day. Dividing the slope (fraction/day) by specific surface area $\left(\mathrm{cm}^{2} / \mathrm{g}\right)$ gives a decay rate, $\mathrm{k}$, with units of $\mathrm{g} /\left(\mathrm{cm}^{2}\right.$ day). The half-life, $\mathrm{t}_{1 / 2}$, is then calculated by dividing 0.693 by slope (Moss and Kanapilly 1980).

The negative exponential model has been used for many previous dissolution studies (Stefaniak 2006, 2008). The non-linear regression models (NLIN) in SAS was used, first with a single component and then with two components. The initial equation was developed in efforts to account for the dissolution of a distribution of particles (Mercer, 1967). The equation is an extremely complex model that accounts for the specific surface area vs. volume ratio in the dissolution equation, (see Appendix I). A possible physical basis for the model is based on the premise that if the largest particle is dissolved then the smaller one must have preceded it because they have a higher SSA to volume ratio. Mercer demonstrated that for geometric standard deviations from 0.5 to $1.0, \mathrm{M} / \mathrm{M}_{0}$ could be simplified to the sum of two exponentials (see Equation 1) based on research by Stefaniak (2006).

$$
\frac{M}{M_{0}}=f_{1} \exp \left(-\lambda_{1} \beta\right)+f_{2} \exp \left(-\lambda_{2} \beta\right)
$$

The second exponential term accounts for any shift in the dissolution kinetics, (see Figure 3), resulting from the transition from small particle dissolution to large particle dissolution.
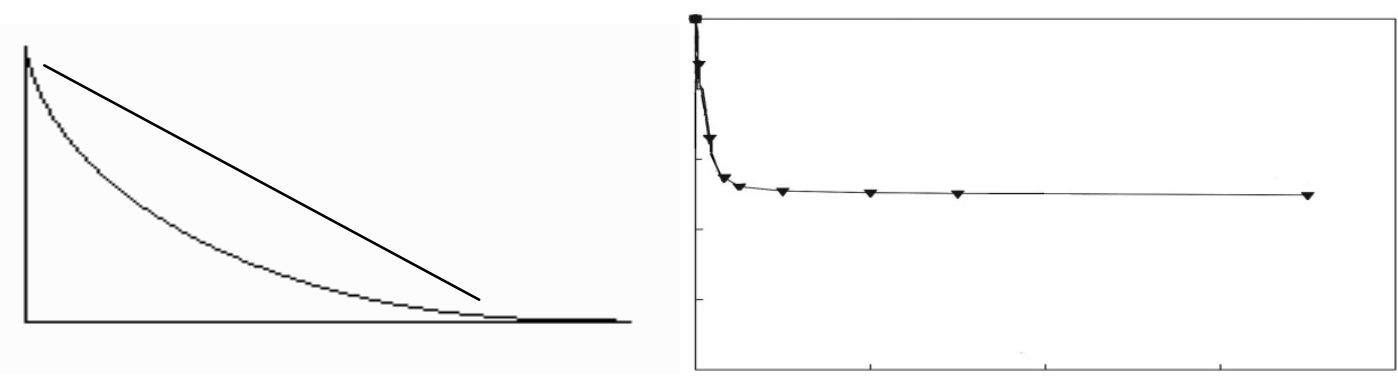

Figure 3. Single (left) and Multiple (right) Component models 
For the purpose of these dissolution studies, the equation above can be reduced further because the Specific Surface Area (SSA) can be measured. The result, Equation 2 is an exponential of the SSA, the rate constant, and time (Stefaniak 2006).

$$
\frac{M}{M_{0}}=\exp (-1.04 k t \mathrm{SSA})
$$

Starting values for the NLIN model (i.e., Equation 3) were based on previous research by Stefaniak (2010). The models were allowed to run for up to 500 iterations to reach convergence or until no further improvement in reaching the convergence criteria was observed. Whether to use the one component or two component model was determined using model convergence and the F-ratio test comparing the model with two components to the model with one component. The slope and intercept of the best fit line were used to calculate the dissolution kinetics, (rate constant and half-time), of the test metal.

$$
\begin{aligned}
\mathrm{y} & =\sum_{\mathrm{i}=1}^{\mathrm{n}} f_{\mathrm{i}} \exp \left(-\lambda_{\mathrm{i}} \mathrm{t}\right), \quad \text { where } \mathrm{y} \text { is } \frac{\mathrm{M}}{\mathrm{M}_{0}} \\
& \sum_{\mathrm{i}=1}^{\mathrm{n}} f_{\mathrm{i}}=100 \% \\
i & =\text { number of dissolution components (one or two) } \\
f_{\mathrm{i}} & =\text { fraction of material available for dissolution in the } \mathrm{i}^{\text {th }} \text { component } \\
\lambda_{\mathrm{i}} & =\mathrm{k}_{\mathrm{i}} \mathrm{SSA} \\
k_{\mathrm{i}} & =\text { chemical dissolution rate constant, } \frac{\mathrm{g}}{\left(\mathrm{cm}^{2} \cdot \mathrm{d}\right)} \\
\text { SSA } & =\text { Specific surface area, } \frac{\mathrm{cm}^{2}}{\mathrm{~g}}
\end{aligned}
$$

\section{Experiment 2 (Effects of Temperature on Bioaccessibility) Methods}

As stated earlier, human skin surface temperature varies from $33^{\circ} \mathrm{C}$ to $45^{\circ} \mathrm{C}$ with a median whole-body value of $36^{\circ} \mathrm{C}$ (Stefaniak and Harvey, 2006). Generally, appendages such as fingers and toes tend to be cooler than the trunk and head. During exercise the skin surface temperature increases to promote evaporation. These variations in skin surface temperature could have an effect on the amount of material that dissolves in human sweat. To investigate this, samples were prepared and analyzed in the same manner as Experiment 1. However, for this experiment there were two separate incubators: one set to $33^{\circ} \mathrm{C}$ and the other set to $45^{\circ} \mathrm{C}$. 
All other facets of the testing remained the same as Experiment 1. The sweat for each changeout was equilibrated to $45^{\circ} \mathrm{C}$ or $33^{\circ} \mathrm{C}$ before it was added to the sample cups to avoid any rampup or step-down time needed for temperature equilibration. The change-outs were performed at the times listed in Table 1.

All statistical analyses were performed as was done for Experiment 1, and the data was compared to Experiment 1 (sweat temperature $36^{\circ} \mathrm{C}, \mathrm{pH} \mathrm{5.3)}$ ) by analyzing the data together with temperature as the covariate to quantify differences in dissolution kinetics with the three temperatures. This is intended to reveal the most optimal of the three physiological temperatures for dissolution of each metal, $(\mathrm{Be}, \mathrm{Cr}, \mathrm{Ni})$, into its bioaccessible form.

\section{Results and Discussion}

All but three samples returned measurable results above the LOD. The final time points of the nickel samples at 33 and $36^{\circ} \mathrm{C}$ did not return values above the LOD, and thus were excluded from the analysis. Dissolution of Be was greater than $\mathrm{Ni}$ or $\mathrm{Cr}$ in all experiments.

\section{Experiment 1}

For a few samples the NLIN model did show convergence for the two component model. However, the differences in the values compared to the single component model were so small that they were not physiologically meaningful. Figures 4, 5, and 6 below show the average $\mathrm{M} / \mathrm{M}_{0}$ of the three replicates and the actual plot of each test material over time. It is clear that the dissolution curve is not biphasic because there is little observed change in dissolution rate. This data shows no time point at which the dissolution significantly changes rate. 


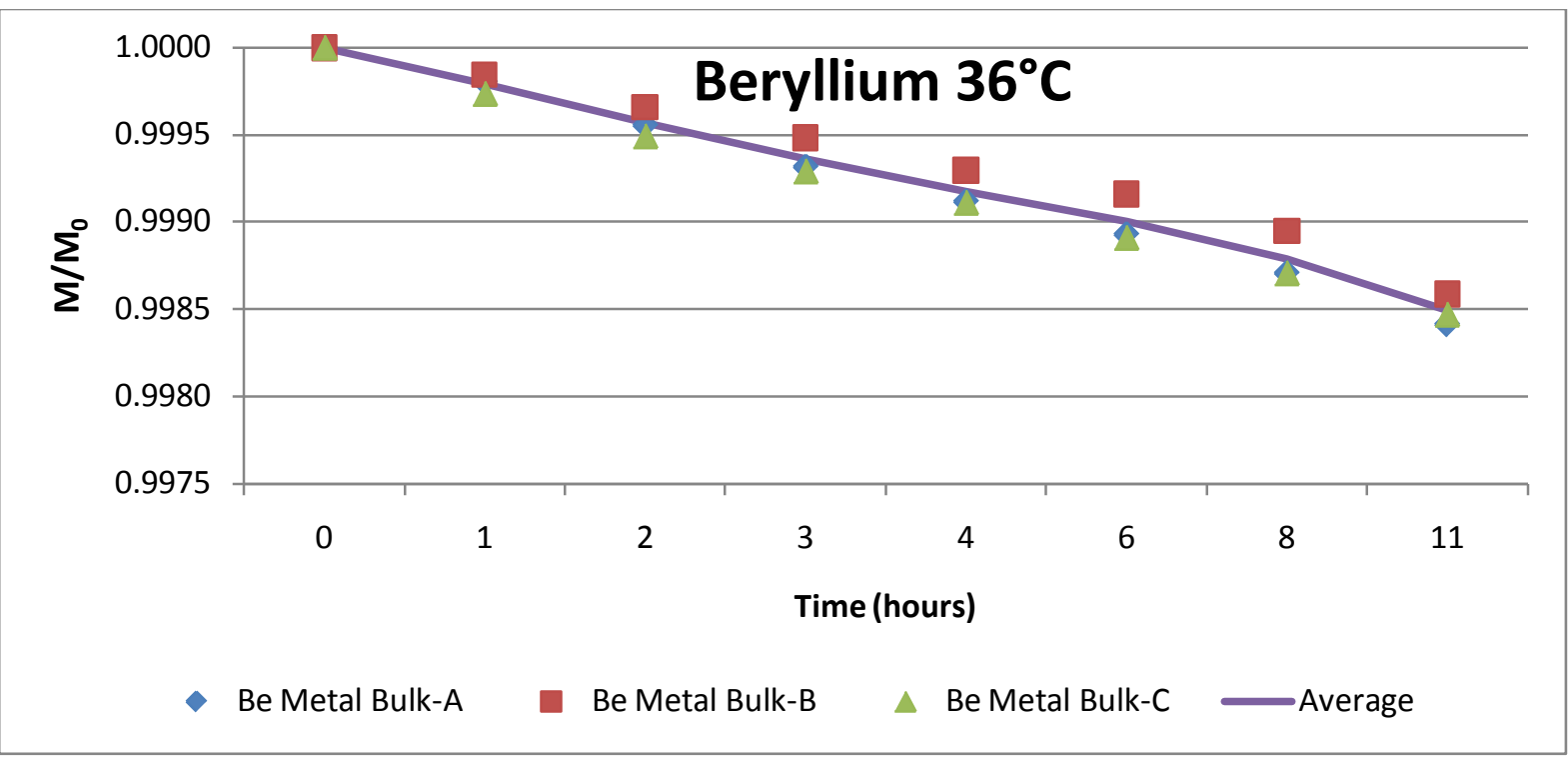

Figure 4. $M / M_{0}$ vs. Time for All Three Samples of Beryllium at $36^{\circ} \mathrm{C}$ and their Average

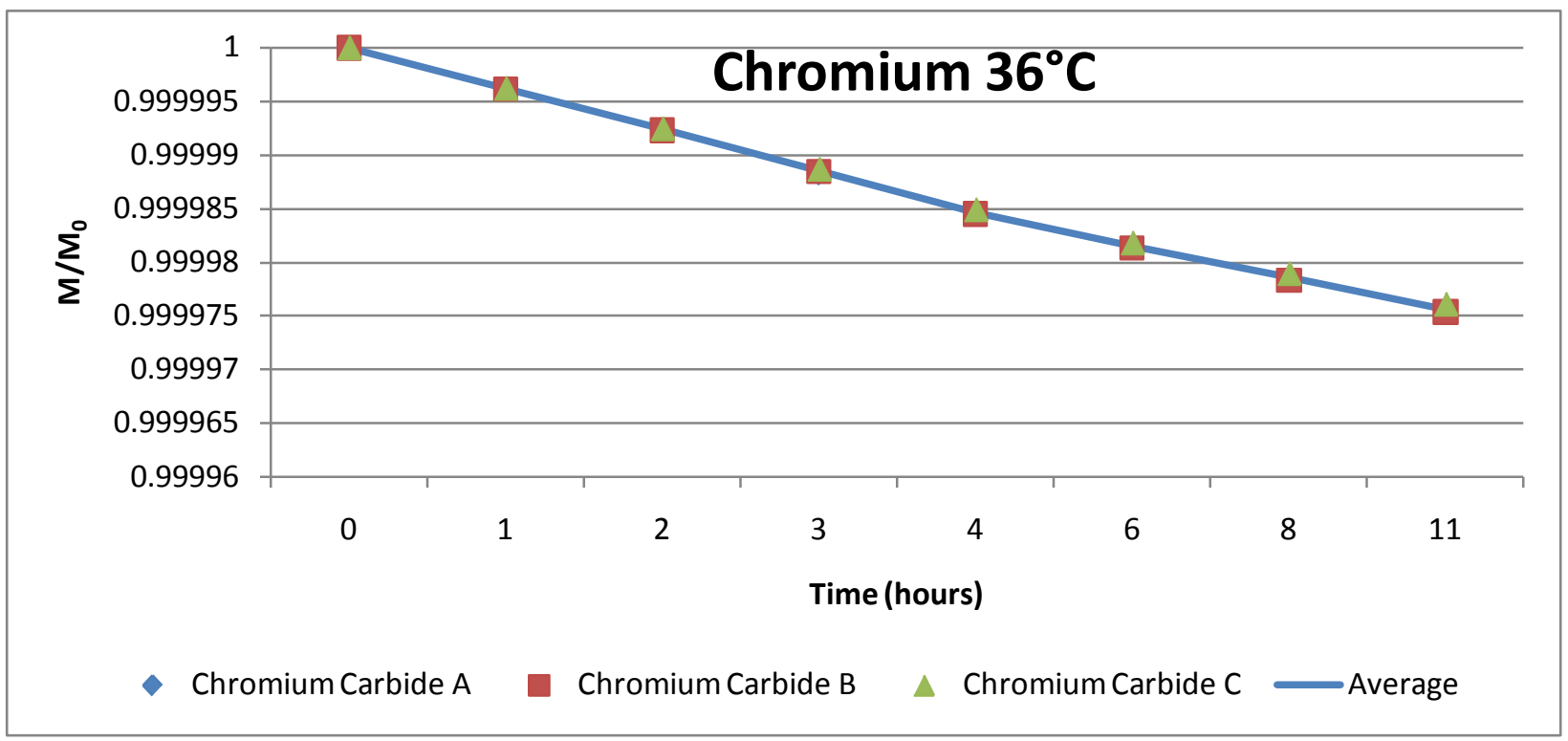

Figure 5. $\mathrm{M} / \mathrm{M}_{0}$ vs. Time for All Three Samples of Chromium at $36^{\circ} \mathrm{C}$ and their Average 


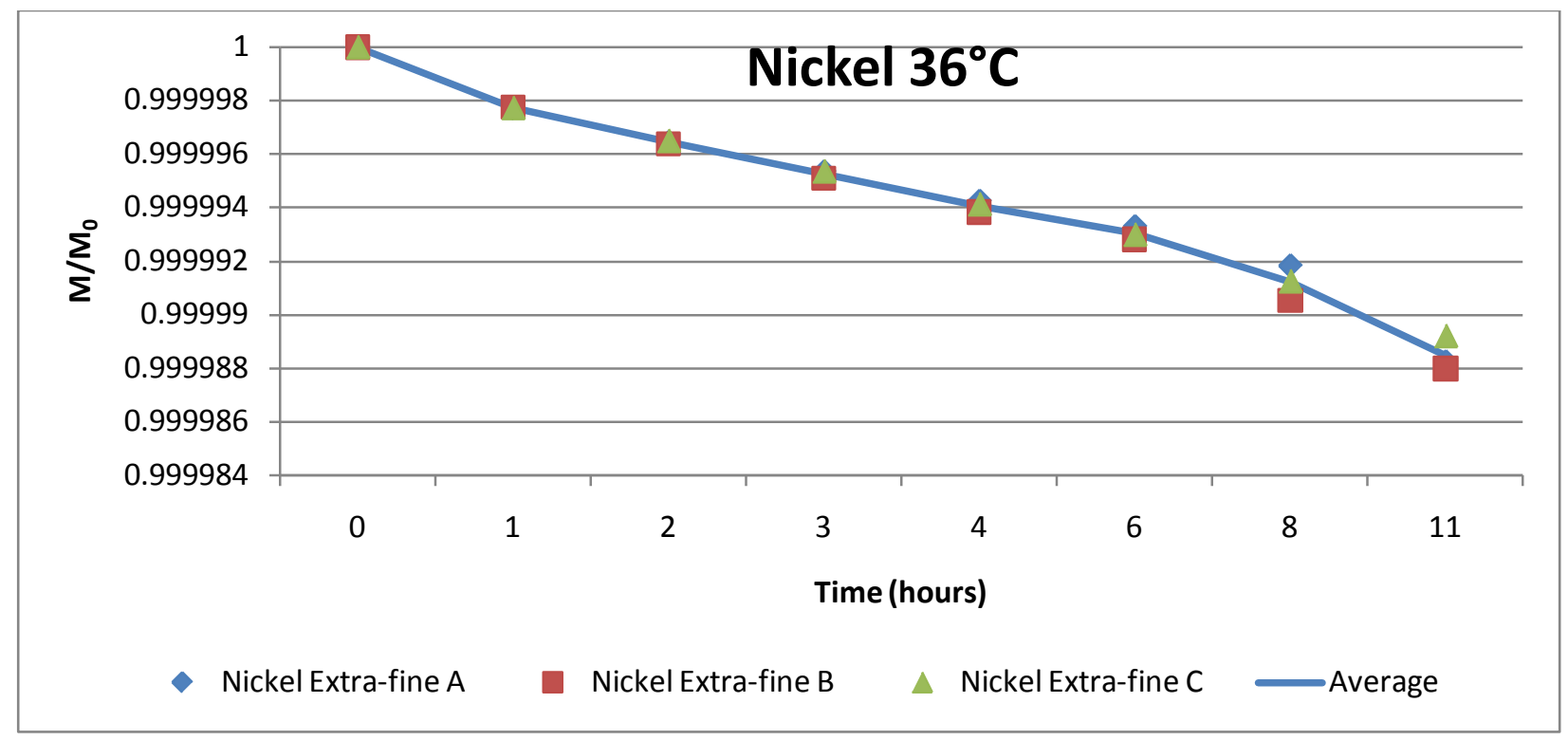

Figure 6. $\mathrm{M} / \mathrm{M}_{0}$ vs. Time for All Three Samples of Beryllium at $36^{\circ} \mathrm{C}$ and their Average

\section{Experiment 2}

Table 2 summarizes the dissolution half-times and rate constants for all the studied metals for each temperature. The half-times for all temperature conditions for Beryllium were similar but in the hundreds of days range. The half-times for Chromium and Nickel for all conditions were in the thousands of days and the rates of dissolution varied by roughly 1 order of magnitude among the materials. For $\mathrm{Be}$ and $\mathrm{Cr}$, k-values were generally not influenced by temperature. In contrast, dissolution of $\mathrm{Ni}$ was influenced by temperature; the rate was faster at $45^{\circ} \mathrm{C}$. This roughly 3 -fold observed increase is consistent with Hemingway and Molokhia (1987) who also observed an approximately 3 fold increase in dissolution rate for every $10^{\circ} \mathrm{C}$ increase in sweat temperature. 
Table 2. Dissolution Kinetics

\begin{tabular}{|l|c|c|c|c|c|}
\hline \multirow{3}{*}{ Powder } & $\begin{array}{c}\text { Temp } \\
\left({ }^{\circ} \mathbf{C}\right)\end{array}$ & $\begin{array}{c}\mathbf{k}\left[\mathbf{g} /\left(\mathbf{c m}^{2} \text { day) }\right]\right. \\
\text { Mean }\end{array}$ & $\begin{array}{c}\text { k-Standard } \\
\text { Deviation }\end{array}$ & $\begin{array}{c}\text { Half-time } \\
\text { Mean } \\
\text { (days) }\end{array}$ & $\begin{array}{c}\text { Half-time } \\
\text { Standard } \\
\text { Deviation }\end{array}$ \\
\hline \multirow{2}{*}{ Be metal } & 33 & $1.02 \mathrm{E}-07$ & $31 \mathrm{E}-09$ & 106.7 & 24.6 \\
\cline { 2 - 6 } & 36 & $0.6 \mathrm{E}-07$ & $3.9 \mathrm{E}-09$ & 211.3 & 14.0 \\
\cline { 2 - 6 } & 45 & $1.1 \mathrm{E}-07$ & $8.7 \mathrm{E}-09$ & 113.7 & 8.3 \\
\hline \multirow{2}{*}{ Chromium Carbide } & 33 & $8.00 \mathrm{E}-09$ & $5.8 \mathrm{E}-10$ & $8,393.8$ & 703.4 \\
\cline { 2 - 6 } & 36 & $5.25 \mathrm{E}-09$ & $87 \mathrm{E}-10$ & $12,789.6$ & 216.2 \\
\cline { 2 - 6 } & 45 & $9.00 \mathrm{E}-09$ & $5.8 \mathrm{E}-10$ & $7,701.2$ & 456.9 \\
\hline \multirow{2}{*}{ Ni metal } & 33 & $2.31 \mathrm{E}-10$ & $2.3 \mathrm{E}-11$ & $39,488.5$ & $3,549.5$ \\
\cline { 2 - 6 } & 36 & $3.33 \mathrm{E}-10$ & $7.4 \mathrm{E}-11$ & $27,358.5$ & $4,966.7$ \\
\cline { 2 - 6 } & 45 & $10.0 \mathrm{E}-10$ & $6.0 \mathrm{E}-11$ & $9,715.5$ & $1,338.5$ \\
\hline
\end{tabular}

An Analysis of Variance (ANOVA) statistical comparison of the temperature rate constant data was performed on each material. The $\mathrm{Be}$ and $\mathrm{Cr} 33^{\circ} \mathrm{C}$ and $45^{\circ} \mathrm{C}$ conditions were grouped together with the $36^{\circ} \mathrm{C}$ condition being slightly statistically different. The Ni data differed with the $33^{\circ}$ and the $36^{\circ} \mathrm{C}$ conditions in the same group and the $45^{\circ} \mathrm{C}$ statistically different, (see Table 3). All tables and graphs from statistical analysis can be seen in Appendix III.

Table 3. Statistical Grouping of Temperature Data

\begin{tabular}{|l|c|c|}
\hline \multicolumn{3}{|c|}{$\begin{array}{c}\text { Means with the same letter are not significantly } \\
\text { different }\end{array}$} \\
\hline $\begin{array}{l}\text { Test } \\
\text { Metal/Temperature }\end{array}$ & Grouping & Mean \\
\hline $\mathrm{Be} / 33^{\circ} \mathrm{C}$ & $\mathrm{B}$ & $1.2 \mathrm{E}-7$ \\
\hline $\mathrm{Be} / 36^{\circ} \mathrm{C}$ & $\mathrm{A}$ & $0.5 \mathrm{E}-7$ \\
\hline $\mathrm{Be} / 45^{\circ} \mathrm{C}$ & $\mathrm{B}$ & $1.1 \mathrm{E}-7$ \\
\hline $\mathrm{Cr} / 33^{\circ} \mathrm{C}$ & $\mathrm{B}$ & $7.9 \mathrm{E}-9$ \\
\hline $\mathrm{Cr} / 36^{\circ} \mathrm{C}$ & $\mathrm{A}$ & $5.2 \mathrm{E}-9$ \\
\hline $\mathrm{Cr} / 45^{\circ} \mathrm{C}$ & $\mathrm{B}$ & $8.6 \mathrm{E}-9$ \\
\hline $\mathrm{Ni} / 33^{\circ} \mathrm{C}$ & $\mathrm{A}$ & $2.5 \mathrm{E}-10$ \\
\hline $\mathrm{Ni} / 36^{\circ} \mathrm{C}$ & $\mathrm{A}$ & $3.7 \mathrm{E}-10$ \\
\hline $\mathrm{Ni} / 45^{\circ} \mathrm{C}$ & $\mathrm{B}$ & $1.0 \mathrm{E}-9$ \\
\hline${ }^{*} \mathrm{All}$ values significant at $\mathrm{p}<5 \%$ & &
\end{tabular}

The difference in k-values within a given material is quite small. However, as seen in Table 3 they are statistically significant with $p$-values less than $5 \%$. However, these differences are not large enough to be of physiological concern. A k-value of 1E-7 was the chosen for beryllium dissolution in sweat as a representative value. The k-value chosen for Chromium was 5E-9 
because no large differences in dissolution rates were noted for any of the conditions. The kvalues for $\mathrm{Ni}$ at $33^{\circ} \mathrm{C}$ and $36^{\circ} \mathrm{C}$ were similar and representative of dissolution on the skin under light work load conditions. As seen in Figures $7 \mathrm{a}$ and $7 \mathrm{~b}$ the $\mathrm{Ni} 45^{\circ} \mathrm{C}$ graph shows a noticeably sharper rate of decline than the $33^{\circ} \mathrm{C}$ graph. Although the total amount dissolved was quite small, there was a discernable difference in the Ni dissolution rate at $45^{\circ} \mathrm{C}$. This temperature condition would be more representative of dissolution on the skin during a heavy work load or hot work conditions.

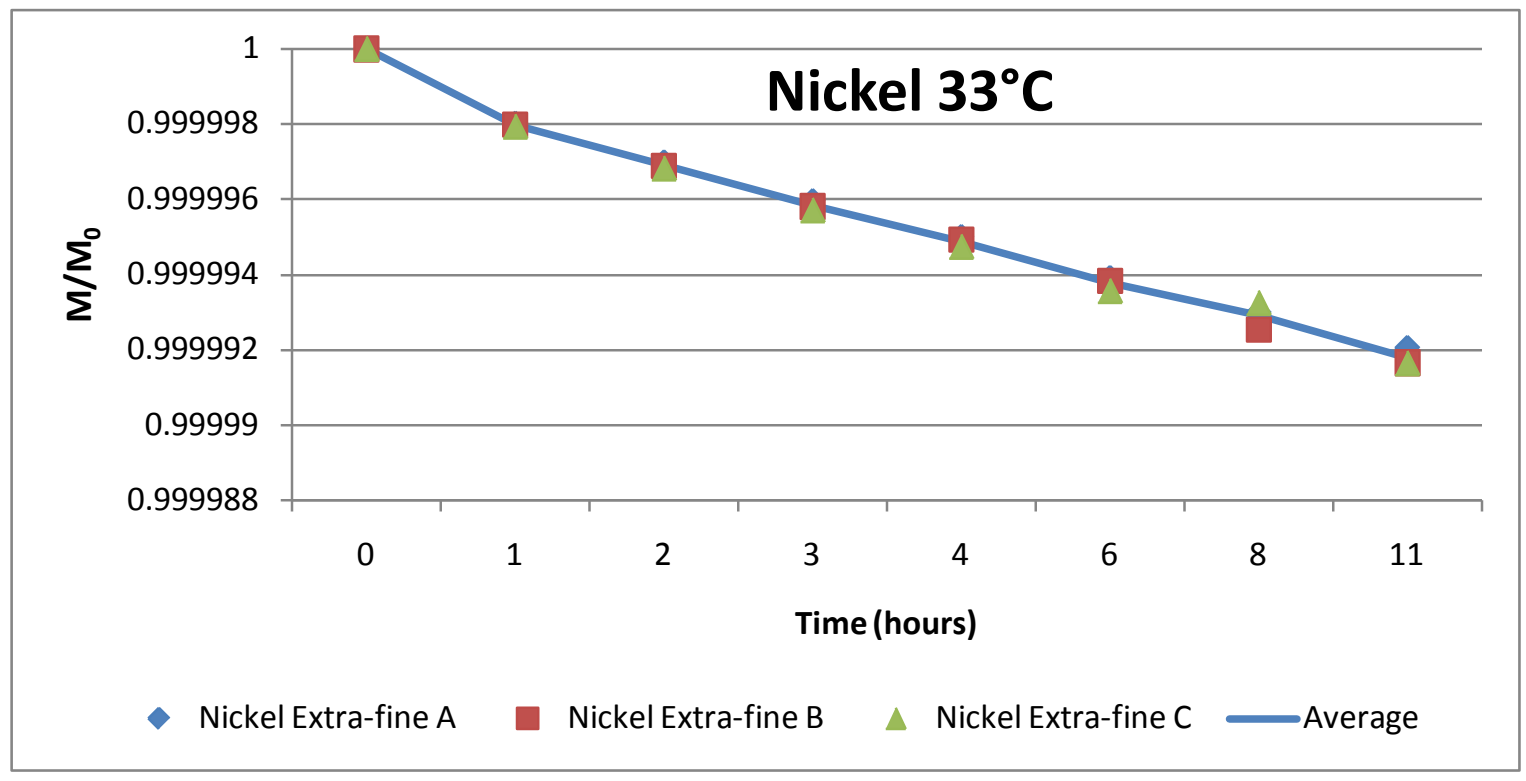

Figure 7a. Average $\mathrm{M} / \mathrm{M}_{0}$ vs. Time for All Three Samples of Nickel at $33^{\circ} \mathrm{C}$ 


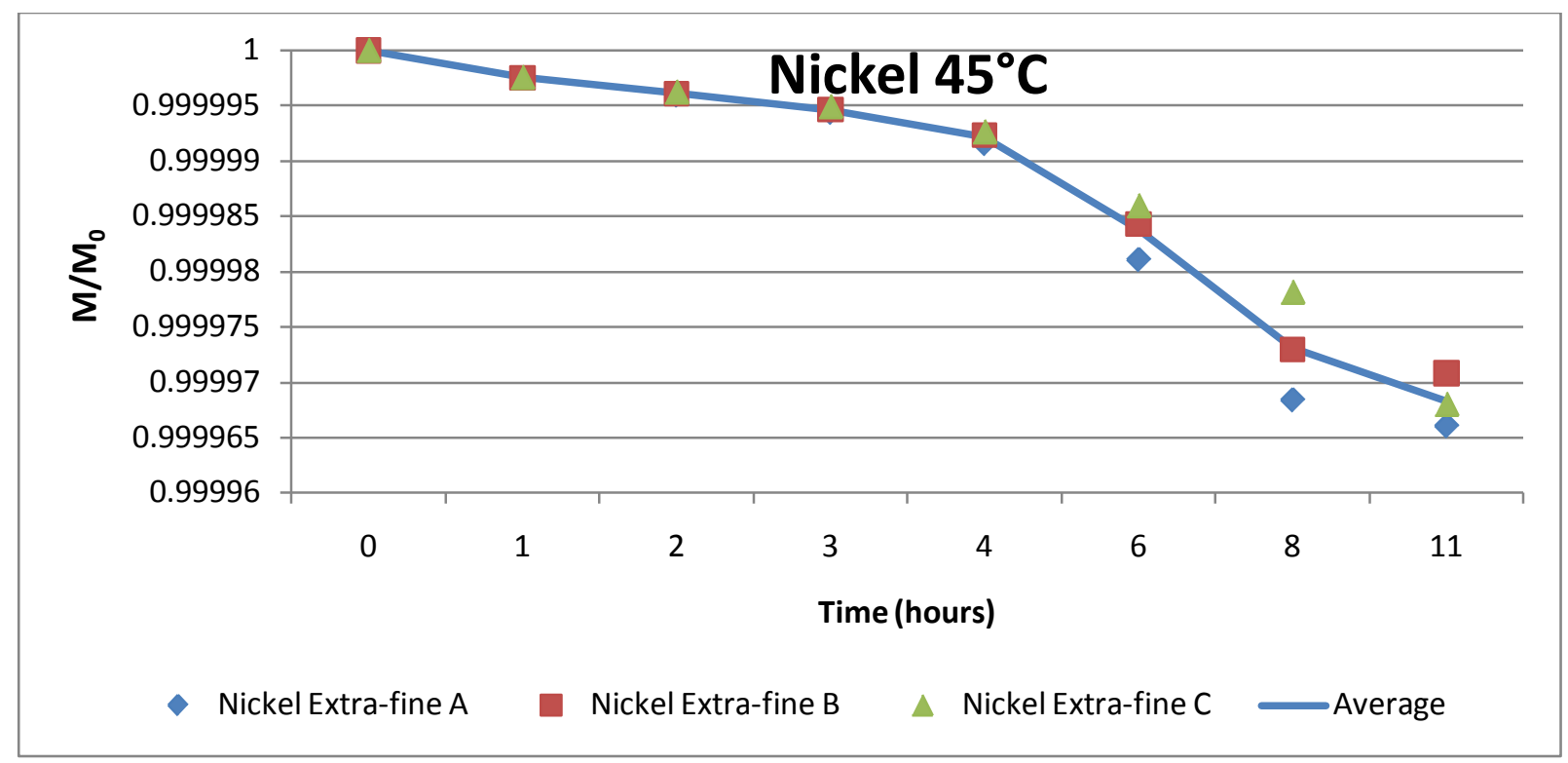

Figure 7b. Average $\mathrm{M} / \mathrm{M}_{0}$ vs. Time for All Three Samples of Nickel at $45^{\circ} \mathrm{C}$

Current analytical protocols for dissolution of metals prior to analysis list test conditions that differ greatly from human skin conditions. Table 4 shows these difference in mean skin conditions and the conditions of sample analysis via the acid dissolution in method NIOSH Manual of Analytical Methods (NMAM) 7303. These differences may produce overestimates of exposure if "mass dissolved into solution" at those conditions is reported without considering bioaccessibility. It is widely accepted that the bioaccessible form of a metal is the form that can penetrate the skin and contribute to the dose. However, dermal exposure samples are currently analyzed using conditions chosen to dissolve all the metal into solution.

Table 4. Acid Digestion (NMAM 7303) vs. Skin Dissolution Conditions for $\mathrm{Be}, \mathrm{Cr}$, and $\mathrm{Ni}$

\begin{tabular}{|c|c|c|c|}
\hline Metal & $\begin{array}{c}\text { Temp } \\
\left({ }^{\circ} \mathbf{C}\right)\end{array}$ & $\begin{array}{c}\text { Time } \\
(\mathbf{M i n})\end{array}$ & $\mathbf{p H}$ \\
\hline Skin Digestion & 36 & 600 & 5.3 \\
\hline Acid Digestion & 95 & 30 & 1 \\
\hline
\end{tabular}

Sample digestion conditions of NMAM 7303 are more extreme than those present on the human skin. In particular, the temperature of $95^{\circ} \mathrm{C}$ is profoundly different from the $36^{\circ} \mathrm{C}$ found on the human skin. Hence, currently employed digestion conditions in NMAM 7303 are unlikely to provide a representative estimate of the mass of metal dissolved on human skin. It is logical for chemical analysis to dissolve all soluble metal into solution for quantification, but this may 
not represent the exposure potential on the skin. The major concern for Be is the amount of dissolved penetrating the skin to initiate sensitization. Also, it has been shown that under the influence of human sweat, pure cobalt and nickel, as well as many alloys containing cobalt, nickel, or chromium will release metal ions at rates sufficient to initiate sensitization and upon repeat exposure elicit allergic contact dermatitis (Julander 2009).

Particle composition, (a chemical property), and simulated sweat fluid characteristics (e.g., composition, $\mathrm{pH}$ ) influence particle dissolution rates, and thus bioaccessibility. For a given combination of particle chemical form and biological fluid, there will be a unique $k$ value. For example, the value of $\mathrm{k}$ for Be metal differs among sweat, airway lining fluid, and macrophage phagolysosomal fluid. Conversely, k of "Be metal" in these three solvents differs from k of Be in the same solvents (Stefaniak 2008).

Human sweat is a variable composition of electrolytes, ionic constituents, organic acids and carbohydrates, amino acids, nitrogenous substances, and vitamins. It is also comprised of differing quantities of nitrous oxide and oxygen with a median $\mathrm{pH}$ of 5.3. Historic and current simulated sweat formulations vary in sweat constituent identity and concentration, $\mathrm{pH}$, and oxygen content under which they are used to estimate chemical dissolution on human skin (Stefaniak 2006). This variability is of concern as it could cause differences in dissolution kinetics thus resulting in a misrepresentation of exposures. At present there are no studies comparing the dissolution behavior of the test metals in the different formulas of simulated sweat.

A set of standardized parameters that are representative of human skin surface conditions are needed to evaluate the bioaccessibility of metal contaminants on human skin. Day et. al $(2007,2009)$ reported that skin contact times with $\mathrm{Ni}$ and $\mathrm{Cr}$ are on the order of several hours and Julander (2009) reports that contact times with metal sensitizers could extend out to several days.

\section{Conclusions}

The results of these dissolution studies demonstrated that $\mathrm{Be}, \mathrm{Cr}$, and $\mathrm{Ni}$ have dissolution halftimes of hundreds of days or more, see Table 2. These times are much longer than reported exposure times in workplace studies. With the exception of $\mathrm{Ni}$, dissolution rates of materials were not influenced by sweat temperature within the $33^{\circ} \mathrm{C}$ to $45^{\circ} \mathrm{C}$ range studied. Thus, a proposed set of physiological relevant conditions for these metal sensitizers are time=10hours, (to ensure inclusion of the longer shifts), and temperature $=36^{\circ} \mathrm{C}$ for light to moderate work. For Nickel an extraction temperature of $45^{\circ} \mathrm{C}$ is appropriate for moderate to heavy work. 


\section{Recommendations}

Ten hours should be selected as the appropriate dissolution period because most workplace skin contact times will be 10 hours or less.

The temperature used for dissolution studies of $\mathrm{Be}$ and $\mathrm{Cr}$ should be $36^{\circ} \mathrm{C}$ because no differences were observed with the varying temperatures within the range of $33^{\circ} \mathrm{C}$ to $45^{\circ} \mathrm{C}$, the range of skin temperatures during work. Nickel should be extracted at $45^{\circ} \mathrm{C}$ if heavy work is present to account for the difference in dissolution rates at the higher temperature.

\section{Limitations}

This study measured the dissolution of the test metals in the formulation of simulated sweat described in Appendix II. The results of this study could vary with different formulas of simulated sweat. Furthermore, the formulation of the test sweat may be different from human sweat for some or all populations.

The dissolution chambers used in this study represent a simplistic simulation of conditions on a sweaty skin. On the skin surface there are many dynamic processes occurring that are very complex and cannot be replicated in the lab. Sweat rate causes variability because not only will particles dissolve but they could also be washed off the skin surface by the sweat. Skin contact time varies because touching contaminated surfaces could result in deposition on skin or removal from skin. Variability can also be caused by loading, the amount of material deposited on the skin. Those limitations of the chambers could affect the dissolution kinetics.

This study provides insight into the dissolution kinetics of the tested metal powders. The dissolution is dependent on particle distribution and characteristics of the sample. The results could vary if powders with different physicochemical properties are tested. 


\section{Acknowledgements}

This study was funded by the National Institute for Occupational Safety and Health (NIOSH),

Division of Respiratory Disease Studies (DRDS), Laboratory Research Branch (LRB),

Morgantown, WV. This project is part of the Exposure Assessment Tools for Airborne Sensitizers

Project managed by Dr. Aleksandr B. Stefaniak. The author acknowledges Dr. Steve Guffey, Dr.

Chris Coffey, and Dr. Abbas Virgi for their statistical expertise and research guidance. 


\section{References}

1. Agache P: Presentation of the skin surface ecosystem. In: Agache $P$, Humbert $P$, editors. Measuring the skin. Germany: Springer-Verlag, p. 21-31 (2004a).

2. Bello D, Herrick CA, Smith TJ, Woskie SR, Streicher RP, Cullen MR, Liu Y, Redlich CA: Skin exposure to isocyanates: reasons for concern. Environ Health Perspect 115(3):328-335 (2007).

3. Berlinger B, Naray M, Sajo I, Zaray G. Critical evaluation of sequential leaching procedures for the determination of $\mathrm{Ni}$ and $\mathrm{Mn}$ species in welding fumes. Ann. Occup. Hyg., Vol 53, No. 4, 333-340 (2009).

4. Chiba A, Sakakura S, Kobayashi K, Kusayanagi K: Dissolution amounts of nickel, chromium and iron from SUS 304, 316 and 444 stainless steels in sodium chloride solutions. J Mater Sci. 3:1995-2000 (1997).

5. Covington JS, McBride MA, Slagle WF, Disney AL: Quantization of nickel and beryllium leakage from base metal castings. J Prosthet Dent. 54:127-136 (1985).

6. Curtis GH: Cutaneous hypersensitivity due to beryllium: a study of thirteen cases. Arch Dermat Syph. 64:470-482 (1951).

7. Day GA, Stefaniak AB, Weston A, Tinkle SS: Beryllium exposure: dermal and immunological considerations. Int Arch Occup Environ Health. 79:161-164 (2006).

8. Day GA, Virji MA, Stefaniak AB: Characterization of exposures among cemented tungsten carbide workers. Part II: Assessment of surface contamination and skin exposures to cobalt, chromium and nickel. J Expo Sci Environ Epidemiol. 19:423-434 (2009).

9. Ellickson KM, Meeker RJ, Gallo MA, Buckley BT, Lioy PJ: Oral bioavailability of lead and arsenic from a NIST standard reference soil material. Arch. Environ. Contam. Toxicol. 40, 128-135 (2001).

10. Forte G, Petrucci F, Bocca B: Metal allergens of growing significance: Epidemiology, immunotoxicology, strategies for testing and prevention. Inflamm Allergy Drug Targets. 7:145-162 (2008).

11. Fournier P-G, Govers TR: Contamination of nickel, copper and zinc during the handling of euro coins. Contact Dermatitis. 48:181-188 (2003).

12. Fullerton A, Andersen JR, Hoelgaard A, Menné T: Permeation of nickel salts through human skin in vitro. Contact Dermat. 15:173-177 (1986). 
13. Hansen MB, Johansen JD, Menné T: Chromium allergy: significance of both $\mathrm{Cr}(\mathrm{III})$ and Cr(VI). Contact Dermatitis. 49:206-212 (2003).

14. Haudrechy P, Foussereau J, Mantout B, Baroux B: Nickel release from 304 and 316 stainless steels in synthetic sweat. Comparison with nickel and nickel-plated metals. Consequences on allergic contact dermatitis. Contact Dermatitis 35:329-336 (1993).

15. Hemingway JD, Molokhia MM: The dissolution of metallic nickel in simulated sweat. Contact Dermatitis. 16:99-105 (1987).

16. Hoover MD, Castorina BT, Finch GL, Rothenberg SJ: Determination of the oxide layer thickness on beryllium metal particles. Am Ind Hyg Assoc J. 50:550-553 (1989).

17. Ikarashi Y, Ohno K, Tsuchiya T, Nakamura A: Differences of draining lymph node cell proliferation among mice, rats and guinea pigs following exposure to metal allergens. Toxicology. 76:283-292 (1992).

18. Julander A, Hindsen M, Skare L, Liden C: Cobalt-containing alloys and the ability to release cobalt and cause dermatitis. Contact Dermatitis. 60: 165-170 (2009).

19. Kreiss K, Mroz MM, Zhen B, Wiedemann H, and Barna B: Risk of beryllium disease related to work processes at a metal, alloy, and oxide production plant. Occup Environ Med. 54:605-612 (1997).

20. Larese Filon F, Maina G, Adami G, Venier M, Coceani N, Bussani R, Massiccio M, Barbieri P, Spinelli P: In vitro percutaneous absorption of cobalt. Int Arch Occup Environ Health. 77:85-89 (2004).

21. Larese F, Gianpietro A, Venier M, Maina G, Renzi N: In vitro percutaneous absorption of metal compounds. Toxicol Lett. 170:49-56 (2007).

22. Mercer TT: On the Role of Particle Size in the Dissolution of Lung Burdens. Health Physics. 13: 1211-1221 (1967).

23. Midlander K, Pan J, Odnevall I, Heim K, Leygraf C: Nickel release from nickel particles in simulated sweat. Contact Dermatitis. 56: 325-330 (2007).

24. Moss OR, Kanapilly GM. Dissolution of inhaled aerosols. In: Wilieke K, ed. Generation of aerosols and ficilides for exposure experiments. Ann Arbor: Science Publishers Inc. 105124 (1980).

25. Redlich CA and Herrick CA: Lung/skin connections in occupational lung disease. Curr Opin Allergy Clin Immunol. 8:115-119 (2008). 
26. Stefaniak AB, Day GA, Harvey CJ, Leonard SS, Schwegler-Berry DE, Chipera SJ, Sahakian NM, Chisholm WP: Characteristics of dusts encountered during the production of cemented tungsten carbides. Ind Health. 45:793-803 (2007).

27. Stefaniak AB, Day GA, Hoover MD, Breysse PN, Scripsick RC: Differences in Dissolution Behavior in a Phagolysosomal Simulant Fluid for Single-Constituent and MultipleConstituent Materials Associated with Beryllium Sensitization and Chronic Beryllium Disease. Toxicol In Vitro. 20: 82-95 (2006).

28. Stefaniak AB, Exposure Assessment for Airborne Sensitizers, Division of Respiratory Disease Studies, National Institute for Occupational Safety and Health approved protocol, (2008).

29. Stefaniak AB, Harvey $C J$ : Dissolution of materials in artificial skin surface film liquids. Toxicol In Vitro. 20:1265-1283 (2006).

30. Stefaniak AB, Virji MA, Day GA: Release of beryllium from beryllium-containing materials in artificial skin surface film liquids. Ann. Occup. Hyg. (Revised), In Press (2010).

31. Thomassen Y, Ellingsen DG, Hetland S et al. Chemical speciation and sequential extraction of MN in workroom aerosols: analytical methodology and results from a field study in MN alloy plans. J Environ. Monit. 3: 559-559 (2001).

32. Tinkle SS, Antonini JM, Rich BA, Roberts JR, Salmen R, DePree K, Adkins EJ: Skin as a route of exposure and sensitization in chronic beryllium disease. Environ Health Perspect. 111:1202-1208 (2003).

33. Tanojo H, Hostynek JJ, Mountford HS, Maibach HI: In vitro permeation of nickel salts through human stratum corneum. Acta Derm Venerol. 212(Suppl):19-23 (2001).

34. Van Lierde V, Chéry CC, Roche M, Monstrey S, Vanhaecke F: In vitro permeation of chromium species through porcine and human skin as determined by capillary electrophoresis-inductively coupled plasma-sector field mass spectrometry. Anal Bioanal Chem. 384:378-384 (2006).

35. Zissu D, Binet $S$, Cavelier C: Patch testing with beryllium alloy samples in guinea pigs. Contact Dermatitis. 34:196-200 (1996). 


\section{Appendix I. Statistical Derivation of Dissolution Equation}

$\frac{M}{M_{0}}=\sum_{i=0}^{3} K_{i} \int_{y_{i}}^{\infty} f(y) \mathrm{d} y$,

where

$f(y) \quad \frac{1}{\sqrt{2} \pi} \exp \left(-\frac{y^{2}}{2}\right)$

$K_{0} \quad 1$

$K_{1}-\beta \exp \left(0.5 \sigma^{2}\right)$

$K_{2} \quad\left(\frac{\beta^{2}}{3}\right) \exp \left(2 \sigma^{2}\right)$

$K_{3} \quad-\left(\frac{\beta^{3}}{27}\right) \exp \left(4.5 \sigma^{2}\right)$

$\sigma \quad \ln \sigma_{\mathrm{g}}$

$\beta \quad \frac{\alpha_{s} k t}{\alpha_{\mathrm{v}} \rho D_{\mathrm{m}}}$

$y_{i} \quad\left(\frac{1}{\sigma}\right) \ln \left(\frac{\beta}{3}\right)+\mathrm{i} \sigma$

Mercer, 1967

The equation and variables represent the original equation developed for the dissolution of a log-normally distributed characterized particle distribution.

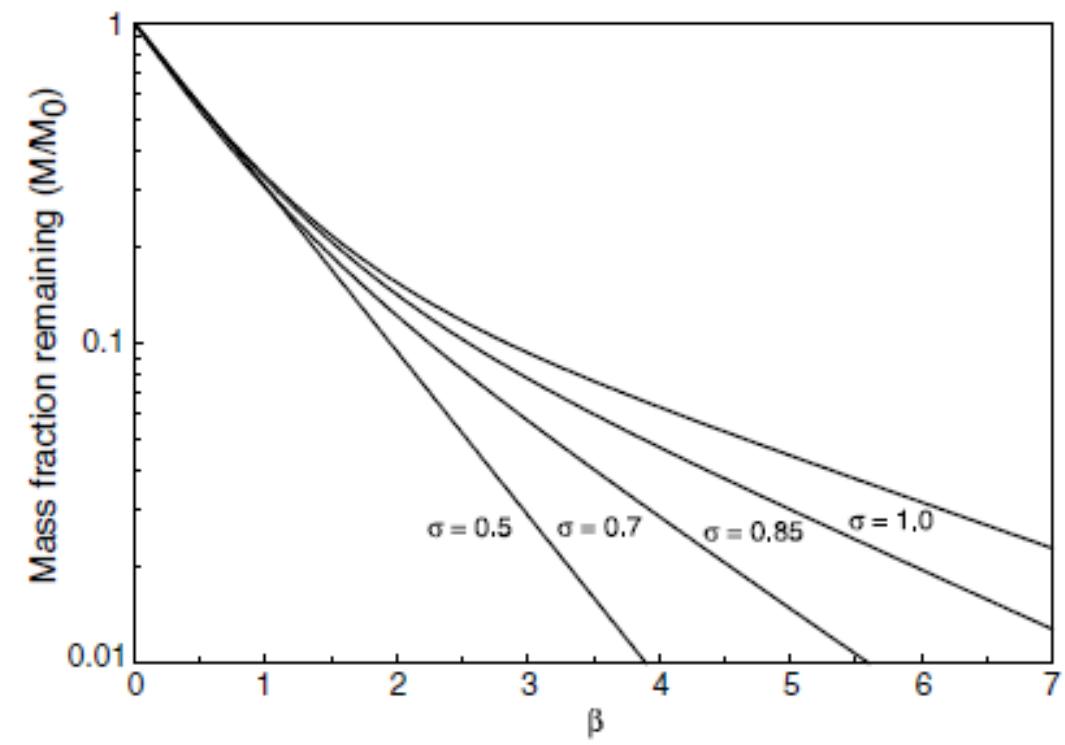

Fig. 2. Mass fraction remaining $\left(\frac{M}{M_{0}}\right)$ for a log-normally distributed population of homogeneous particles as a function of $\beta$ and $\sigma$ according to Eq. (3) (adapted from Mercer, 1967). 


\section{Appendix II. (Excerpted and amended from Simulated Human Sweat Protocol, Stefaniak and Harvey, 2006)}

\section{Simulant Preparation}

In this study, the effect of sweat on dissolution of Be metal, Ni metal, and $\mathrm{CrC}_{3}$ powders was evaluated. To do this study, we will need:

- $15 \mathrm{~L}$ of simulated sweat having pH 5.3 (see Sections I to III)

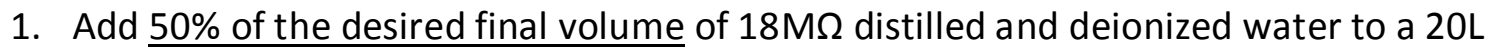
container

2. Place propeller stirrer and temperature probe in the container then begin to stir at $\sim 500$ rpm while warming overnight to $37^{\circ} \mathrm{C}$ on hotplate (Model 11-800-495SHP, Fisher Scientific, Dubuque, IA)

3. Connect the inlet side of an in-line HEPA filter (HEPA-CAP 36, Whatman Inc., Florham Park, $\mathrm{NJ})$ to the house air supply then connect the aeration tubing loop to the outlet side of the filter

4. Place the aeration loop in the water into the flask and bubble air into the water overnight to saturate with air

5. Remove aeration tubing loop and increase the rpm of the propeller stirrer until a deep vortex is made in the liquid

6. Calibrate a microbalance (Model XS205, Mettler-Toledo, Greifensee, Switzerland) using its internal balance calibration weight then verify using a Class 1 calibration weight (Cat\# 854254.1, Denver Instruments, Arvada, CA)

7. Place a weighing dish on the calibrated balance and tare

8. Beginning with sodium sulfate, measure the appropriate quantity of each constituent for each batch of simulated sweat

9. Record the weighed mass of constituent in this document or a laboratory notebook

10. Carefully transfer the weighed mass of constituent into the appropriate carboy then rinse the weighing dish with dd-water to ensure complete transfer into beaker

NB: rinse water should be used sparingly to ensure complete removal of residual material from weigh dish while not adding too much extra liquid to container

11. Using a new weighing dish (or pipet tip for liquids) for each constituent, repeat steps for the remaining constituents in the order listed in the tables below

12. Special handling requirements are necessary for some of the vitamins and these steps must be followed exactly to successfully prepare the sweat:

a. Nicotinic acid should be weighed out in a tri-cornered plastic beaker and slowly added scoop-by-scoop to the sweat solution

b. D-pantothenic acid can be rapidly added to the sweat solution 
13. The amounts of some chemical constituents in the table are too small to be weighed accurately on the balance or dispensed by our pipets, necessitating modification of the protocol. If necessary, prepare the following stock solutions:

a. Sodium lodide: make concentrated solution by dissolving $0.010 \mathrm{~g} \mathrm{Nal}$ in $0.050 \mathrm{~L}$ water; pipet appropriate volume into beaker

b. Sodium Fluoride: make concentrated solution by dissolving $0.025 \mathrm{~g} \mathrm{NaF}$ in $0.050 \mathrm{~L}$ water; pipet appropriate volume into beaker

c. Sodium Bromide: make concentrated solution by dissolving $0.015 \mathrm{~g} \mathrm{NaBr}$ in 0.050L water; pipet appropriate volume into beaker

d. Cadmium Chloride Anhydrous: make concentrated solution by dissolving $0.010 \mathrm{~g}$ $\mathrm{CdCl}_{2}$ in $0.050 \mathrm{~L}$ water; pipet appropriate volume into beaker

e. Copper Chloride Dihydrate: make concentrated solution by dissolving $0.010 \mathrm{~g}$ $\mathrm{CuCl}_{2} \cdot 2 \mathrm{H}_{2} \mathrm{O}$ in $0.050 \mathrm{~L}$ water; pipet appropriate volume into beaker

f. Manganese Chloride: make concentrated solution by dissolving $0.010 \mathrm{~g} \mathrm{MnCl}_{2}$ in $0.050 \mathrm{~L}$ water; pipet appropriate volume into beaker

g. Hexanoic Acid: make concentrated solution by pipeting $1.0 \mathrm{~mL}$ hexanoic acid in $0.050 \mathrm{~L}$ water; pipet appropriate volume into beaker

h. Isobutyric Acid: make concentrated solution by pipeting $1.0 \mathrm{~mL}$ isobutyric acid in $0.050 \mathrm{~L}$ water; pipet appropriate volume into beaker

i. Isovaleric Acid: make concentrated solution by pipeting $1.0 \mathrm{~mL}$ isovaleric acid in $0.050 \mathrm{~L}$ water; pipet appropriate volume into beaker

j. Creatinine: make concentrated solution by dissolving $2.400 \mathrm{~g}$ creatinine in $0.250 \mathrm{~L}$ water; pipet appropriate volume into beaker

k. Creatine monohydrate: make concentrated solution by dissolving $1.000 \mathrm{~g}$ creatinine monohydrate in $0.250 \mathrm{~L}$ water; pipet appropriate volume into beaker

I. Pyridoxine Hydrochloride: make concentrated solution by dissolving $0.010 \mathrm{~g}$ pyridoxine hydrochloride in $0.050 \mathrm{~L}$ water; pipet appropriate volume into beaker

m. Folic Acid: make concentrated solution by dissolving $0.010 \mathrm{~g}$ folic acid in $0.050 \mathrm{~L}$ water; pipet appropriate volume into beaker

If necessary, add drop of $5 \mathrm{~N} \mathrm{NaOH}$ to clear folic acid stock solution

n. Ascorbic Acid: make concentrated solution by dissolving $0.090 \mathrm{~g}$ ascorbic acid in $0.050 \mathrm{~L}$ water; pipet appropriate volume into beaker

o. Inositol: make concentrated solution by dissolving $0.015 \mathrm{~g}$ inositol in $0.050 \mathrm{~L}$ water; pipet appropriate volume into beaker

p. Choline Chloride: make concentrated solution by dissolving $1.000 \mathrm{~g}$ choline chloride in $0.050 \mathrm{~L}$ water; pipet appropriate volume into beaker

q. p-Aminobenzoic Acid: make concentrated solution by dissolving $0.010 \mathrm{~g} \mathrm{p}$ aminobenzoic acid in $0.050 \mathrm{~L}$ water; pipet appropriate volume into beaker 
To dispense the required aliquots use the pipettes for the appropriate volumes listed in Table I.

Table I. Pipet Models and Relative Volumes

\begin{tabular}{lc}
\hline \multicolumn{1}{c}{ Pipet } & Range $(\mu \mathrm{L})^{*}$ \\
\hline Rainin P2 & 0.2 to 2 \\
Rainin P20 & 2 to 20 \\
Rainin P200 & 50 to 200 \\
Rainin EDP1000 & 100 to 1000 \\
Eppendorf 5000 & 500 to 5000 \\
\hline
\end{tabular}

$* 1000 \mu \mathrm{L}=1 \mathrm{~mL}=0.001 \mathrm{~L}$

Table II. Simulated sweat formulation (multiply quantities by appropriate volume being prepared)

\begin{tabular}{|c|c|c|}
\hline Sweat Constituent & Mass (g/L) & Volume $(\mu \mathrm{L} / \mathrm{L})$ \\
\hline \multicolumn{3}{|l|}{ Primary electrolytes and ionic constituents } \\
\hline Sodium Sulfate $\left(\mathrm{Na}_{2} \mathrm{SO}_{4}\right)$ & 0.0583 & --- \\
\hline Sodium lodide (Nal) & --- & 53.2 \\
\hline Sodium Fluoride (NaF) & --- & 923.6 \\
\hline Sodium Bromide (NaBr) & --- & 788.8 \\
\hline Cadmium Chloride Anhydrous $\left(\mathrm{CdCl}_{2}\right)$ & --- & 16.5 \\
\hline Copper (II) Chloride Dihydrate $\left(\mathrm{CuCl}_{2} \cdot 2 \mathrm{H}_{2} \mathrm{O}\right)$ & --- & 801.3 \\
\hline 1M Ammonium Hydroxide $\left(\mathrm{NH}_{4} \mathrm{OH}\right)$ & --- & 5200.0 \\
\hline Sulfur (S)* & 0.0737 & --- \\
\hline Iron Sulfate Heptahydrate $\left(\mathrm{FeSO}_{4} \cdot 7 \mathrm{H}_{2} \mathrm{O}\right)$ & 0.0027 & --- \\
\hline Lead (Pb)- Reference Solution 1000ppm & --- & 24.9 \\
\hline Manganese (II) Chloride $\left(\mathrm{MnCl}_{2}\right)$ & --- & 692.1 \\
\hline Nickel (Ni)- Reference Solution 1000ppm & --- & 24.6 \\
\hline Zinc (Zn)- Reference Solution 1000ppm & --- & 850.3 \\
\hline Sodium Bicarbonate $\left(\mathrm{NaHCO}_{3}\right)$ & 0.2520 & --- \\
\hline Potassium Chloride (KCl) & 0.4547 & --- \\
\hline Magnesium Chloride Hexahydrate $\left(\mathrm{MgCl}_{2} \cdot 6 \mathrm{H}_{2} \mathrm{O}\right)$ & 0.0167 & --- \\
\hline
\end{tabular}


Sodium Phosphate Anhydrous Monobasic $\left(\mathrm{NaH}_{2} \mathrm{PO}_{4}\right)$

Phosphorous Pentachloride $\left(\mathrm{PCl}_{5}\right)$

Sodium Chloride

Organic acids and carbohydrates

\subsection{4}

0.0027

1.5519

\begin{tabular}{|c|c|c|}
\hline $1 \mathrm{M} \mathrm{L}(+)$-lactate solution $\left(\mathrm{CH}_{3} \mathrm{CH}(\mathrm{OH}) \mathrm{COOH}\right)$ & --- & 14000.0 \\
\hline Pyruvic acid $\left(\mathrm{C}_{3} \mathrm{H}_{4} \mathrm{O}_{3}\right)$ & --- & 12.7 \\
\hline Butyric acid $\left(\mathrm{C}_{4} \mathrm{H}_{8} \mathrm{O}_{2}\right)$ & --- & 0.22 \\
\hline Acetic acid $\left(\mathrm{C}_{2} \mathrm{H}_{4} \mathrm{O}_{2}\right)$ & --- & 7.4 \\
\hline Hexanoic acid $\left(\mathrm{C}_{6} \mathrm{H}_{12} \mathrm{O}_{2}\right)$ & --- & 5.7 \\
\hline Propionic acid $\left(\mathrm{C}_{3} \mathrm{H}_{6} \mathrm{O}_{2}\right)$ & --- & 0.26 \\
\hline Isobutyric acid $\left(\mathrm{C}_{4} \mathrm{H}_{8} \mathrm{O}_{2}\right)$ & --- & 3.7 \\
\hline Isovaleric acid $\left(\mathrm{C}_{5} \mathrm{H}_{10} \mathrm{O}_{2}\right)$ & --- & 6.0 \\
\hline $\mathrm{D}(+)$-Glucose $\left(\mathrm{C}_{6} \mathrm{H}_{12} \mathrm{O}_{6}\right)$ & 0.0306 & --- \\
\hline \multicolumn{3}{|l|}{ Amino acids } \\
\hline DL-Alanine $\left(\mathrm{C}_{3} \mathrm{H}_{7} \mathrm{NO}_{2}\right)$ & 0.0511 & --- \\
\hline $\mathrm{L}-(+)$-Arginine $\left(\mathrm{C}_{6} \mathrm{H}_{14} \mathrm{~N}_{4} \mathrm{O}_{2}\right)$ & 0.1359 & --- \\
\hline $\mathrm{L}-(+)$-Aspartic acid $\left(\mathrm{C}_{4} \mathrm{H}_{7} \mathrm{NO}_{4}\right)$ & 0.0453 & --- \\
\hline L-(+)-Citrulline $\left(\mathrm{C}_{6} \mathrm{H}_{13} \mathrm{~N}_{3} \mathrm{O}_{3}\right)$ & 0.0701 & --- \\
\hline $\mathrm{L}-(+)$-Glutamic acid $\left(\mathrm{C}_{5} \mathrm{H}_{9} \mathrm{NO}_{4}\right)$ & 0.0544 & --- \\
\hline Glycine $\left(\mathrm{C}_{2} \mathrm{H}_{5} \mathrm{NO}_{2}\right)$ & 0.0293 & --- \\
\hline L-Histidine $\left(\mathrm{C}_{6} \mathrm{H}_{9} \mathrm{~N}_{3} \mathrm{O}_{2}\right)$ & 0.0807 & --- \\
\hline L-Isoleucine $\left(\mathrm{C}_{6} \mathrm{H}_{13} \mathrm{NO}_{2}\right)$ & 0.0223 & --- \\
\hline L-Leucine $\left(\mathrm{C}_{6} \mathrm{H}_{13} \mathrm{NO}_{2}\right)$ & 0.0275 & --- \\
\hline $\mathrm{L}-(+)$-Lysine Monohydrochloride $\left(\mathrm{C}_{6} \mathrm{H}_{14} \mathrm{~N}_{2} \mathrm{O}_{2} \cdot \mathrm{HCl}\right)$ & 0.0274 & --- \\
\hline $\mathrm{L}-(+)$-Ornithine Monohydrochloride $\left(\mathrm{C}_{5} \mathrm{H}_{12} \mathrm{~N}_{2} \mathrm{O}_{2} \cdot \mathrm{HCl}\right)$ & 0.0253 & --- \\
\hline L-Phenylalanine $\left(\mathrm{C}_{9} \mathrm{H}_{11} \mathrm{NO}_{2}\right)$ & 0.0215 & --- \\
\hline L-Threonine $\left(\mathrm{C}_{4} \mathrm{H}_{9} \mathrm{NO}_{3}\right)$ & 0.0536 & --- \\
\hline
\end{tabular}




\section{Sweat Constituent}

L-(-)-Tryptophan $\left(\mathrm{C}_{11} \mathrm{H}_{12} \mathrm{~N}_{2} \mathrm{O}_{2}\right)$

L-Tyrosine $\left(\mathrm{C}_{9} \mathrm{H}_{11} \mathrm{NO}_{3}\right)$

L-Valine $\left(\mathrm{C}_{5} \mathrm{H}_{11} \mathrm{NO}_{2}\right)$

Nitrogenous Substances
Mass (g/L) Volume $(\mu \mathrm{L} / \mathrm{L})$

$\begin{array}{ll}0.0112 & -- \\ 0.0308 & -- \\ 0.0293 & ---\end{array}$

0.0112

$\begin{array}{lcc}\text { Ammonium } & & --- \\ \text { Uric acid }\left(\mathrm{C}_{5} \mathrm{H}_{4} \mathrm{~N}_{4} \mathrm{O}_{3}\right) & --- & --- \\ \text { Urea }\left(\mathrm{CH}_{4} \mathrm{~N}_{2} \mathrm{O}\right) & 0.0099 & --- \\ \text { Creatinine }\left(\mathrm{C}_{4} \mathrm{H}_{7} \mathrm{~N}_{3} \mathrm{O}\right) & 0.6006 & 989.8 \\ \text { Creatine Monohydrate }\left(\mathrm{C}_{4} \mathrm{H}_{9} \mathrm{~N}_{3} \mathrm{O}_{2} \cdot \mathrm{H}_{2} \mathrm{O}\right) & --- & 559.3\end{array}$

\section{Vitamins}

Thiamine Hydrochloride $\left(\mathrm{C}_{12} \mathrm{H}_{17} \mathrm{ClN} \mathrm{N}_{4} \mathrm{OS} \cdot \mathrm{HCl}\right)$

1.6863

0.0753

Riboflavin $\left(\mathrm{C}_{17} \mathrm{H}_{20} \mathrm{~N}_{4} \mathrm{O}_{6}\right)^{* *}$

Nicotinic Acid $\left(\mathrm{C}_{6} \mathrm{H}_{5} \mathrm{NO}_{2}\right) * *$

D-Pantothenic Acid Calcium Salt $\left(\left(\mathrm{C}_{9} \mathrm{H}_{17} \mathrm{NO}_{5}\right)_{2} \mathrm{Ca}\right)$

Pyridoxine Hydrochloride $\left(\mathrm{C}_{8} \mathrm{H}_{11} \mathrm{NO}_{3} \cdot \mathrm{HCl}\right)$

Folic Acid $\left(\mathrm{C}_{19} \mathrm{H}_{19} \mathrm{~N}_{7} \mathrm{O}_{6}\right)$

L-(+)-Ascorbic Acid $\left(\mathrm{C}_{6} \mathrm{H}_{8} \mathrm{O}_{6}\right)$

Dehydroascorbic Acid ${ }^{2}$

Inositol $\left(\mathrm{C}_{6} \mathrm{H}_{12} \mathrm{O}_{6}\right)$

Choline Chloride $\left(\mathrm{C}_{5} \mathrm{H}_{14} \mathrm{NOCl}\right)$
50.4751

2.4780

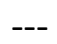

$---$

$---$

- $\quad 100 \mathrm{~mL}$

$--$

$---$

$--$
10.3

35.3

978.5

960.9

181.5

48.7

${ }^{1}$ Added as ammonium hydroxide with primary electrolytes and ionic constituents

${ }^{2}$ If necessary, prepare dehydroascorbic acid solution by mixing $0.0352 \mathrm{~g}$ ascorbic acid in $2 \mathrm{~L}$ water then add $0.2 \mathrm{~mL}$ ascorbate oxidase enzyme and incubate solution at $37^{\circ} \mathrm{C}$ for 30 minutes

* Upon addition of Sulfur, solution may turn faint yellow color and should remain mostly clear until addition of vitamins 
** Upon addition of riboflavin, solution will turn orange and cloudy

*** Upon addition of nicotinic acid, solution will turn vivid yellow and remain cloudy 


\section{Dissolving vitamins and adjusting $\mathrm{pH}$}

1. Calibrate pH electrode (InLab413, Mettler-Toledo) connected to a mV meter (SevenMulti, Mettler-Toledo) using three calibration standards:

a. pH 4 (Cat\# SB98-1, Fisher Scientific)

b. pH 7 (Cat\# SB108-1, Fisher Scientific)

c. $\mathrm{pH} 10$ (Cat\# SB116-1, Fisher Scientific)

2. Special handling requirements are necessary to completely dissolve the vitamins (riboflavin, nicotinic acid, and D-pantothenic acid) and these steps must be followed exactly to successfully prepare the sweat:

a. Upon addition of p-aminobenzoic acid, allow solution to stir for 5 minutes then turn stirrer off (continue to heat solution at $37^{\circ} \mathrm{C}$ )

b. Allow solution to rest for 5 minutes or until white undissolved solids (nicotinic acid) visibly separate from the yellow solution

c. Add $10 \mathrm{~mL}$ of $5 \mathrm{~N}$ sodium hydroxide to container using a serological pipet

When adding $\mathrm{NaOH}$, place tip of pipet in liquid just above solids then dispense

d. Immediately turn stirrer back on for 5 minutes, then turn off

If necessary, use long rod to help dislodge solids from edge of container and assist with mixing

e. Allow solution to rest for at least 5 minutes while white undissolved solids separate from yellow liquid

f. Add $10 \mathrm{~mL}$ of $5 \mathrm{~N}$ sodium hydroxide as described above

g. Immediately turn stirrer back on for 5 minutes, then turn off

h. Repeat this sequence of settling, adding sodium hydroxide, stirring, using appropriate increments of sodium hydroxide

NB: See example below for profile of base addition and stirring used to dissolve vitamins and raise $\mathrm{pH}$ of $5 \mathrm{~L}$ simulated sweat

At $\sim \mathrm{pH} 4.8$, solution will become drastically clearer

i. After this rapid solution clearing point is reached, continue to add sodium hydroxide in smaller increments followed by stirring and settling. Check pH of the solution after each addition of base and continue sequence until sweat solution $\mathrm{pH}=5.3$

Return sweat solution used for $\mathrm{pH}$ check to the mixing container 
3. Once sweat solution $\mathrm{pH}$ has been raised to the desired value, continue to stir solution at $37^{\circ} \mathrm{C}$

4. The next morning, dilute simulated sweat solution to final volume (15L) using aerated $18 \mathrm{M} \Omega$ distilled and deionized water

5. Verify the final $\mathrm{pH}$ of each solution and if necessary, using microliter quantities of $5 \mathrm{~N}$ sodium hydroxide, adjust to final $\mathrm{pH}$ of $5.3 \pm 0.1$

Table III. Profile used to dissolve vitamins and adjust $\mathrm{pH}$ for $5 \mathrm{~L}$ of simulated sweat

\begin{tabular}{llll}
\hline Settling time $(\mathrm{min})$ & $5 \mathrm{~N} \mathrm{NaOH}(\mathrm{mL})$ & Stir time $(\mathrm{min})$ & $\mathrm{pH}$ \\
\hline 15 & 10 & 5 & -- \\
5 & 10 & 5 & -- \\
5 & 20 & 5 & -- \\
5 & 20 & 5 & -- \\
5 & 20 & 5 & -- \\
5 & 20 & 5 & -- \\
5 & 20 & 5 & $4.8 *$ \\
2 to 3 & 10 & 5 & 4.9 \\
2 to 3 & 10 & 5 & 4.97 \\
2 to 3 & 10 & 5 & 5.06 \\
2 to 3 & 10 & 5 & 5.13 \\
2 to 3 & 5 & 5 & 5.23 \\
2 to 3 & 5 & 5 & 5.29 \\
2 to 3 & 5 & 5 & 5.29 \\
2 to 3 & 1 & overnight & 5.35 \\
\hline
\end{tabular}

* Solution became visibly clearer 


\section{Appendix III. (Excerpted and amended from Dissolution of Beryllium Compounds in Artificial Skin Surface Film Liquids, Stefaniak, 2008)}

\section{Loading of Filter Sandwiches}

1. Calibrate a microbalance using the internal balance calibration weight, then verify using a Class 1 calibration weight

2. Using tweezers, place the $47 \mathrm{~mm}$ nitrocellulose filter with $0.025-\mu \mathrm{m}$ pore size on the lower ring of the dissolution chamber

3. Place the filter and lower chamber ring on the microbalance and tare

4. Using a clean spatula, carefully add at least the required minimum mass of bulk or sizeseparated powder to the filter

5. Record the actual mass of powder for each sample on same sheet with sebum filter weight data

6. CAREFULLY place a second $0.025-\mu \mathrm{m}$ pore nitrocellulose filter on top of the powder and the $47 \mathrm{~mm}$ nitrocellulose filter to encase the material

7. Place an o-ring on top of the filter assembly

8. Gently place the top half of the chamber on the assembly and screw together using 4 nylon screws

9. Place each static dissolution chamber in a clean re-sealable plastic bag

10. Using a permanent ink marker label the contents and sample number on the bag

11. Repeat steps until all static dissolution chambers have been assembled

12. Prepare the six remaining filter sandwiches without powder for use as QC samples:

\section{Experimental Set up, Monitoring, and Sample Collection}

1. Using a sterile pipet or beaker, add $80 \mathrm{~mL}$ of simulated sweat to each appropriately labeled autoclaved polypropylene jars with screw-top lid

"Appropriately labeled" means the contents and sample number are legible and in permanent ink on the lid and side of the jar

2. Screw the lid on each jar and place all jars in the incubator at the appropriate temperature overnight to equilibrate solvent temperature. For this experiment, we will use one incubator for $33^{\circ} \mathrm{C}$ samples and another for $45^{\circ} \mathrm{C}$ samples

3. The next morning, quickly and carefully remove jars one at a time from the incubator, unscrew the lid, place a static dissolution chamber in the simulated sweat, cover, and return to the incubator 
4. Record the sample identification, time that the chamber was placed in liquid, and any other pertinent information on the Sample Data Sheet

5. Repeat steps until all static dissolution chambers, including the Field Blanks have been immersed in simulated sweat and placed in the incubator

6. Using a sterile pipet, add $80 \mathrm{~mL}$ of simulated sweat to the empty labeled autoclaved polypropylene jars with screw-top lid and place in incubator to equilibrate solvent prior to next scheduled change out

7. At each pre-determined time point, remove a sample jar and a jar containing equilibrated solvent one at a time from the incubator and unscrew the lids

Time points are hr 1, hr 2, hr 3, hr 4, hr 6, hr 8, and hr 11

8. Using plastic forceps, gently remove the dissolution chamber from the solvent and carefully shake to remove excess liquid

9. Transfer the powder-exposed liquid into a clean numbered borosilicate glass sample jar and record the sample contents, time, and any other pertinent data on the Sample Data Sheet

10. Place each borosilicate glass jar in the water bath by the surface area analyzer to maintain the desired temperature

11. Return the static dissolution chamber to its appropriate container, immerse in equilibrated solvent, cover with lid, and return to incubator

12. Repeat steps until the solvent has been changed in all samples

13. Using a sterile pipet or beaker, add $80 \mathrm{~mL}$ of fresh simulated sweat to each of the empty labeled autoclaved polypropylene jars with screw-top lid and place in incubator to equilibrate solvent prior to next scheduled change out

14. Measure the $\mathrm{pH}$ of solvent in each borosilicate glass sample jar at the desired temperature using calibrated electrode

a. Record the sample $\mathrm{pH}$ (and temperature if more than $\pm 0.5^{\circ} \mathrm{C}$ from the set temp) on the "pH Monitoring Data Sheet"

b. Rinse probe with distilled and deionized water and blot dry between samples

15. After determining $\mathrm{pH}$ of all samples, weigh each jar

16. Place jars in $-10^{\circ} \mathrm{C}$ freezer for storage until analysis by spectroscopy

\section{Quality Control Samples}

1. Reagent blanks

a. Filter sandwiches containing sebum-coated filters at a ratio of 1 in 10 prepared dissolution chambers (see $\S \mathrm{V}$ )

b. $80 \mathrm{~mL}$ of simulated sweat at a ratio of 2 in 10 collected solvent samples

i. Blinded reagent blanks at ratio of 1 in 10 collected solvent samples

ii. Identified reagent blanks at ratio of 1 in 10 collected solvent samples 
2. Field blanks

a. Simulated sweat at same pre-determined time points as the experimental samples 


\section{Appendix IV. Data Tables from SAS Analysis}

The tables show the statistical reports from the SAS calculation of temperature effects. The graphs of from each element at each temperature condition are below. The black dotted lines represent the average of the three replicates.

Table I. Beryllium Statistical Results

\begin{tabular}{|l|r|}
\hline Alpha & 0.05 \\
\hline Error Degrees of Freedom & 6 \\
\hline Error Mean Square & $3.58 \mathrm{E}-16$ \\
\hline Critical Value of Studentized Range & 4.33920 \\
\hline Minimum Significant Difference & $47 \mathrm{E}-9$ \\
\hline
\end{tabular}

\begin{tabular}{|c|c|c|c|c|}
\hline \multicolumn{5}{|c|}{ Comparisons significant at the 0.05 level are indicated by ${ }^{* * *}$. } \\
\hline $\begin{array}{l}\text { Solvent } \\
\text { Comparison }\end{array}$ & $\begin{array}{r}\text { Difference } \\
\text { Between } \\
\text { Means }\end{array}$ & $\begin{array}{l}\text { Simult } \\
\text { Confid }\end{array}$ & $\begin{array}{l}\text { L } 95 \% \\
\text { Limits }\end{array}$ & \\
\hline SSFL5.3_t 36 - SSFL5.3_t45 & $5.04707 \mathrm{E}-\mathrm{s}$ & $3.0959 \mathrm{E}-9$ & $9.78455 \mathrm{E}-\mathrm{s}$ & $\cdots$ \\
\hline SSFL5.3_t 36 - SSFL5.3_t 33 & $6.20049 E-8$ & $1.46301 E-8$ & $1.0938 E-7$ & $\cdots$ \\
\hline SSFL5.3_t45 - SSFL5.3_t36 & $-5.0471 \mathrm{E}-8$ & $-9.7845 E-8$ & $-3.0959 E-9$ & $\cdots$ \\
\hline SSFL $5.3 \mathrm{t} 45$-SSFL5.3 t 33 & $1.15342 \mathrm{E}-8$ & $-3.5841 \mathrm{E}-\mathrm{S}$ & $5.3909 \mathrm{E}-8$ & \\
\hline SSFL $5.3 \mathrm{t} 33-\mathrm{SSFL} 5.3 \mathrm{t} 36$ & $-6.2005 \mathrm{E}-8$ & $-1.0938 E-7$ & $-1.463 \mathrm{E}-8$ & $\cdots$ \\
\hline SSFL5.3_t33 - SSFL5.3_t45 & $-1.1534 E-8$ & $-5.8909 \mathrm{E}-8$ & $3.58406 \mathrm{E}-\mathrm{S}$ & \\
\hline
\end{tabular}

\begin{tabular}{|l|r|}
\hline Alpha & 0.05 \\
\hline Error Degrees of Freedom & 6 \\
\hline Error Mean Square & $3.53 \mathrm{E}-16$ \\
\hline Critical Value of Studentized Range & 4.33920 \\
\hline Minimum Significant Difference & $47 \mathrm{E}-9$ \\
\hline
\end{tabular}

\begin{tabular}{|l|r|r|l|}
\hline \multicolumn{4}{|c|}{$\begin{array}{c}\text { Means with the same letter are not } \\
\text { significantly different. }\end{array}$} \\
\hline Tukey Grouping & Mean & N & Solvent \\
\hline A & -5.8744 E-8 & 3 & SSFL5.3_t36 \\
\hline & & & \\
\hline B & $-1.0921 \mathrm{E}-7$ & 3 & SSFL5.3_t45 \\
\hline B & & & \\
\hline B & $-1.2075 \mathrm{E}-7$ & 3 & SSFL5.3_t33 \\
\hline
\end{tabular}


Table II. Chromium Statistical Results

\begin{tabular}{|l|r|}
\hline Alpha & 0.05 \\
\hline Error Degrees of Freedom & 6 \\
\hline Error Mean Square & $2.23 \mathrm{E}-19$ \\
\hline Critical Value of Studentized Range & 4.33920 \\
\hline Minimum Significant Difference & $12 \mathrm{E}-10$ \\
\hline
\end{tabular}

\begin{tabular}{|c|c|c|c|c|}
\hline \multicolumn{5}{|c|}{ Comparisons significant at the 0.05 level are indicated by $* * *$. } \\
\hline $\begin{array}{c}\text { Solvent } \\
\text { Comparison }\end{array}$ & $\begin{array}{r}\text { Difference } \\
\text { Between } \\
\text { Means }\end{array}$ & $\begin{array}{l}\text { Simultan } \\
\text { Confider }\end{array}$ & $\begin{array}{l}\text { eous } 95 \% \\
\text { lce Limits }\end{array}$ & \\
\hline SSFL5.3_t36 - SSFL5.3_t33 & $2.76314 E-9$ & $1.57891 \mathrm{E}-9$ & $3.94738 E-9$ & $\cdots$ \\
\hline SSFL5.3_t36 - SSFL5.3_t45 & $3.46146 \mathrm{E}-9$ & $2.27722 \mathrm{E}-9$ & $4.64569 \mathrm{E}-9$ & $\cdots$ \\
\hline SSFL5.3_t33 - SSFL5.3_t36 & $-2.7631 \mathrm{E}-9$ & $-3.9474 E-9$ & $-1.5789 E-9$ & $\cdots$ \\
\hline SSFL5.3_t33 - SSFL5.3_t45 & $6.9831 \mathrm{E}-10$ & $-4.859 E-10$ & $1.88255 E-9$ & \\
\hline SSFL5.3_t45 - SSFL5.3_t36 & $-3.4615 \mathrm{E}-9$ & $-4.6457 \mathrm{E}-9$ & $-2.2772 \mathrm{E}-9$ & $\cdots$ \\
\hline SSFL5.3_t45 - SSFL5.3_t 33 & $-6.983 \mathrm{E}-10$ & $-1.8825 E-9$ & 4. $8593 \mathrm{E}-10$ & \\
\hline
\end{tabular}

\begin{tabular}{|l|r|}
\hline Alpha & 0.05 \\
\hline Error Degrees of Freedom & 6 \\
\hline Error Mean Square & $2.23 \mathrm{E}-19$ \\
\hline Critical Value of Studentized Range & 4.33920 \\
\hline Minimum Significant Difference & $12 \mathrm{E}-10$ \\
\hline
\end{tabular}

\begin{tabular}{|l|r|r|l|}
\hline \multicolumn{4}{|c|}{$\begin{array}{c}\text { Means with the same letter are not } \\
\text { significantly different. }\end{array}$} \\
\hline Tukey Grouping & Mean & N & Solvent \\
\hline A & $-5.211 \mathrm{E}-9$ & 3 & SSFL5.3_t36 \\
\hline & & & \\
\hline B & $-7.9742 \mathrm{E}-9$ & 3 & SSFL5.3_t33 \\
\hline B & & & \\
\hline B & $-3.6725 \mathrm{E}-9$ & 3 & SSFL5.3_t45 \\
\hline
\end{tabular}


Table III. Nickel Statistical Results

\begin{tabular}{|l|r|}
\hline Alpha & 0.05 \\
\hline Error Degrees of Freedom & 6 \\
\hline Error Mean Square & $9.07 \mathrm{E}-21$ \\
\hline Critical Value of Studentized Range & 4.33920 \\
\hline Minimum Significant Difference & $24 \mathrm{E}-11$ \\
\hline
\end{tabular}

\begin{tabular}{|c|c|c|c|c|}
\hline \multicolumn{5}{|c|}{ Comparisons significant at the 0.05 level are indicated by $* * *$. } \\
\hline $\begin{array}{c}\text { Solvent } \\
\text { Comparison }\end{array}$ & $\begin{array}{r}\text { Difference } \\
\text { Between } \\
\text { Means }\end{array}$ & $\begin{array}{l}\text { Simultar } \\
\text { Confide }\end{array}$ & $\begin{array}{l}\text { eous } 95 \% \\
\text { ce Limits }\end{array}$ & \\
\hline SSFL5.3_t33 - SSFL5.3_t36 & $1.1813 \mathrm{E}-10$ & $-1.205 \mathrm{E}-10$ & $3.5676 \mathrm{E}-10$ & \\
\hline SSFL5.3_t33 - SSFL5.3_t45 & $7.7585 \mathrm{E}-10$ & $5.3721 \mathrm{E}-10$ & $1.01448 E-9$ & $\cdots$ \\
\hline SSFL5.3_t36 - SSFL5.3_t33 & $-1.181 E-10$ & $-3.568 \mathrm{E}-10$ & 1.2051E-10 & \\
\hline SSFL5.3_t 36 - SSFL5.3_t45 & $6.5772 \mathrm{E}-10$ & $4.1909 \mathrm{E}-10$ & S.9636E-10 & $\cdots$ \\
\hline SSFL5.3_t45 - SSFL5.3_t 33 & $-7.758 E-10$ & $-1.0145 \mathrm{E}-9$ & $-5.372 \mathrm{E}-10$ & $\cdots$ \\
\hline SSFL5.3_t45 - SSFL5.3_t 36 & $-6.577 \mathrm{E}-10$ & $-8.964 E-10$ & $-4.191 \mathrm{E}-10$ & $\cdots$ \\
\hline
\end{tabular}

\begin{tabular}{|l|r|}
\hline Alpha & 0.05 \\
\hline Error Degrees of Freedom & 6 \\
\hline Error Mean Square & $9.07 E-21$ \\
\hline Critical Value of Studentized Range & 4.33920 \\
\hline Minimum Significant Difference & $24 E-11$ \\
\hline
\end{tabular}

\begin{tabular}{|l|r|r|l|}
\hline \multicolumn{5}{|c|}{$\begin{array}{c}\text { Means with the same letter are not } \\
\text { significantly different. }\end{array}$} \\
\hline Tukey Grouping & Mean & N & Solvent \\
\hline A & $-2.507 E-10$ & 3 & SSEL5.3_t33 \\
\hline A & & & \\
\hline A & $-3.688 E-10$ & 3 & SSEL5.3_t36 \\
\hline & & & \\
\hline B & $-1.0265 E-9$ & 3 & SSEL5.3_t45 \\
\hline
\end{tabular}




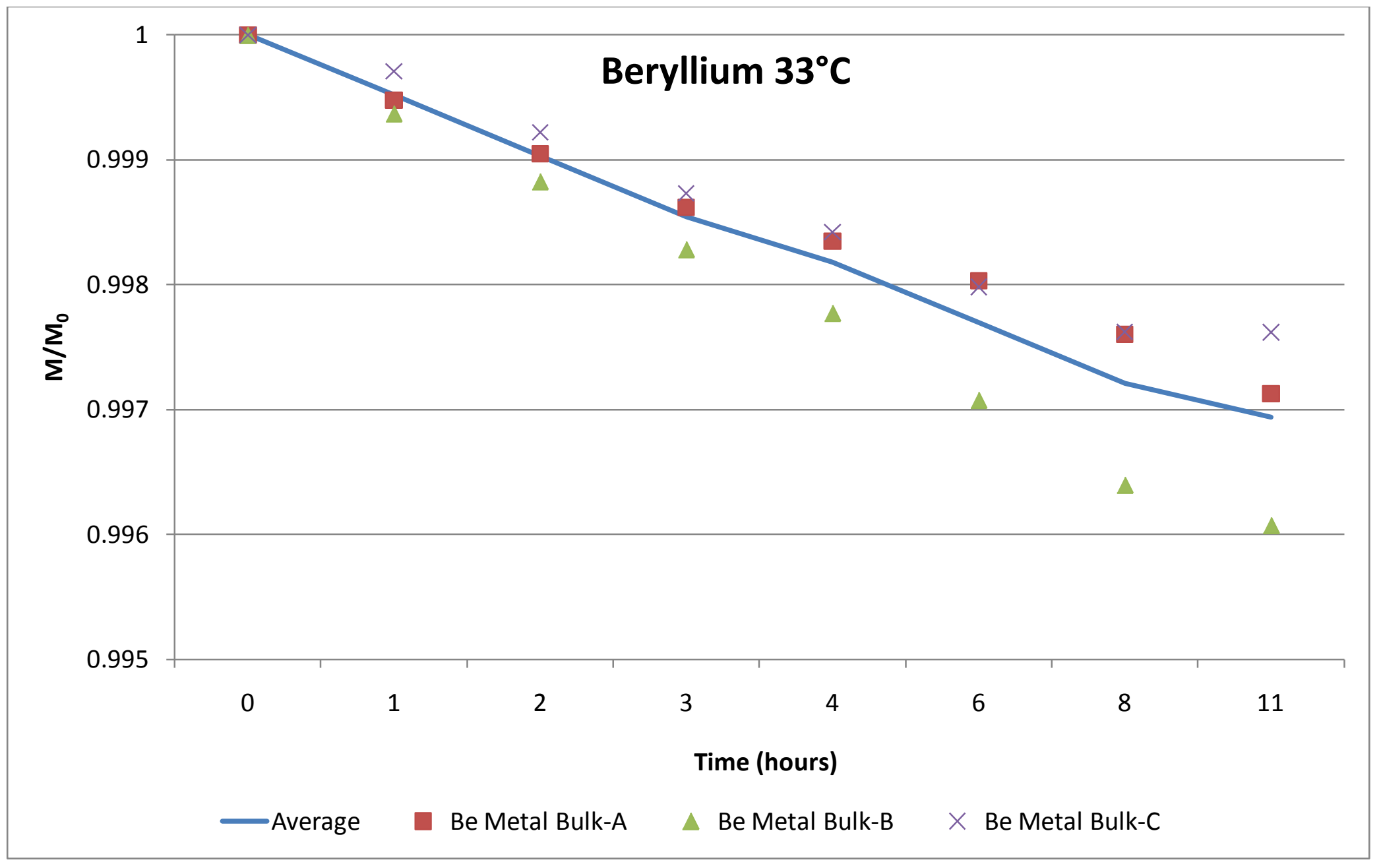




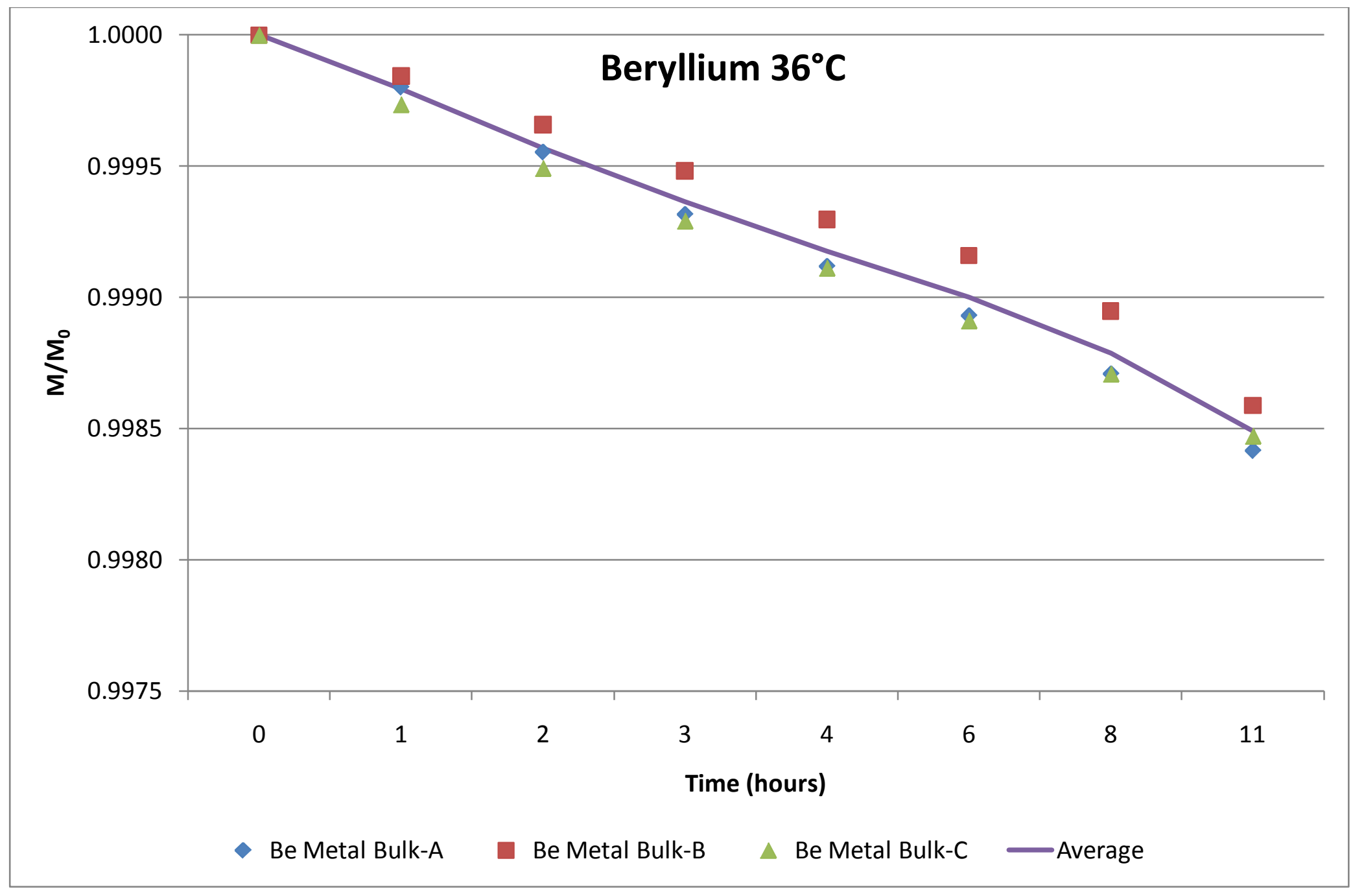




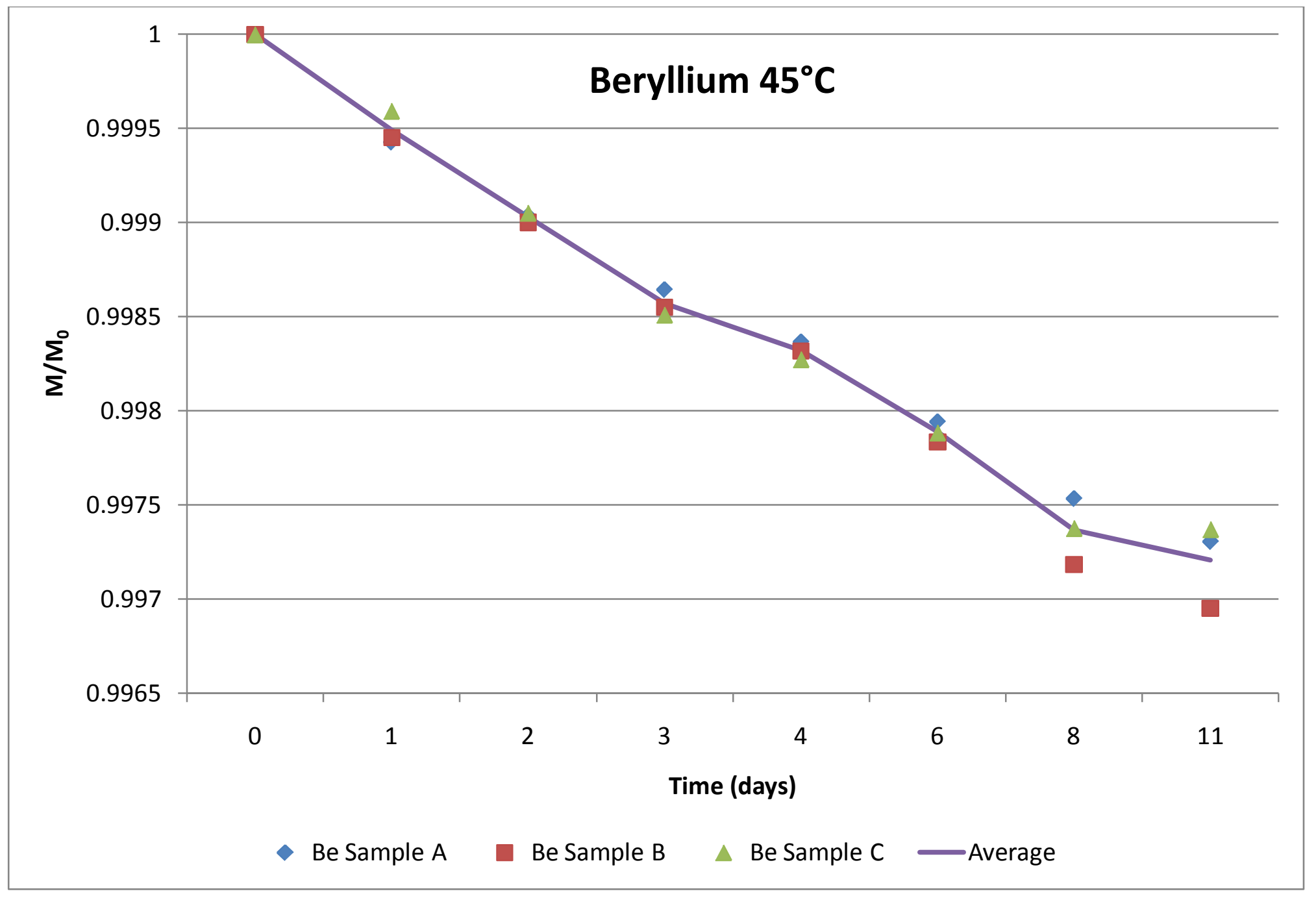




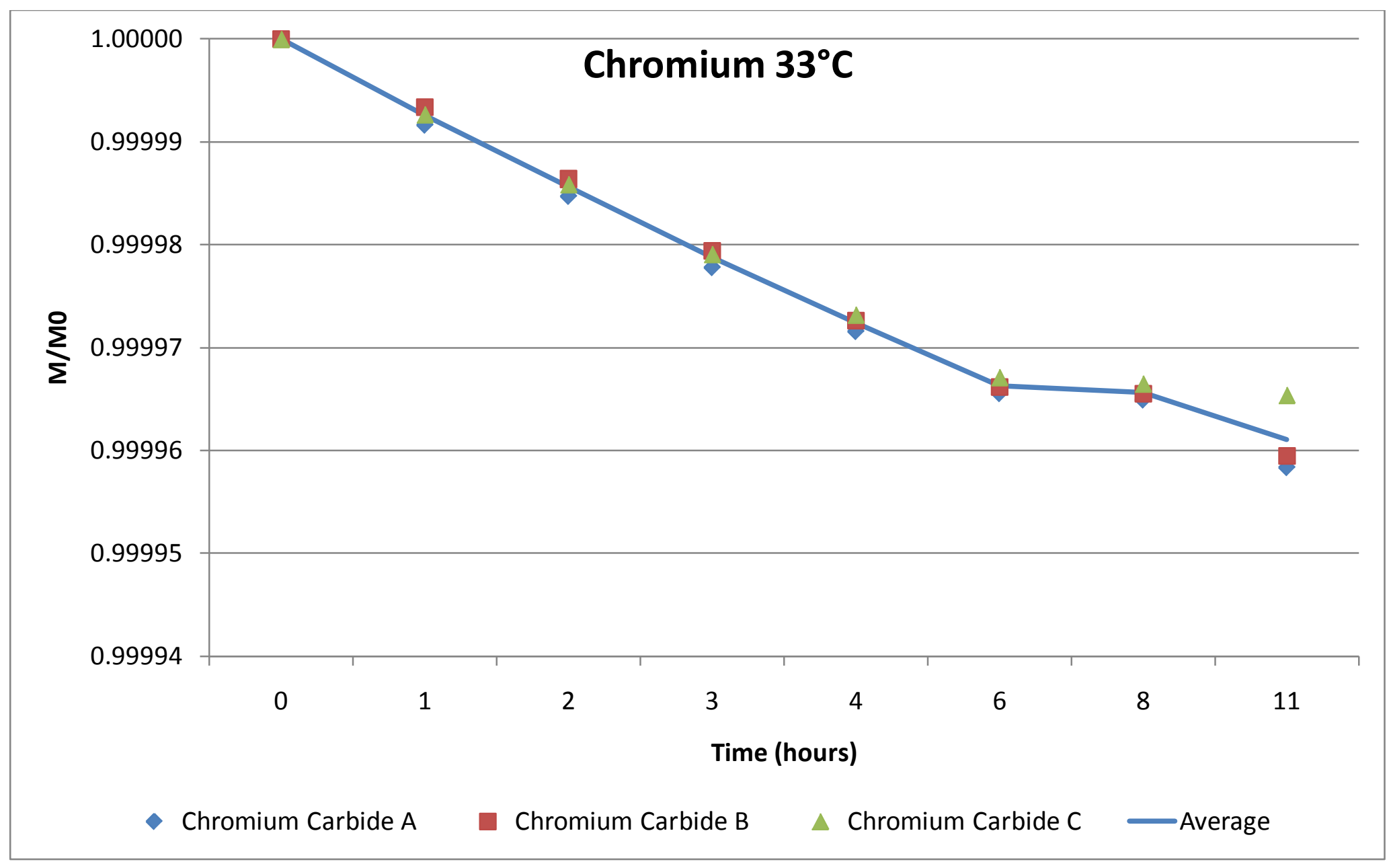




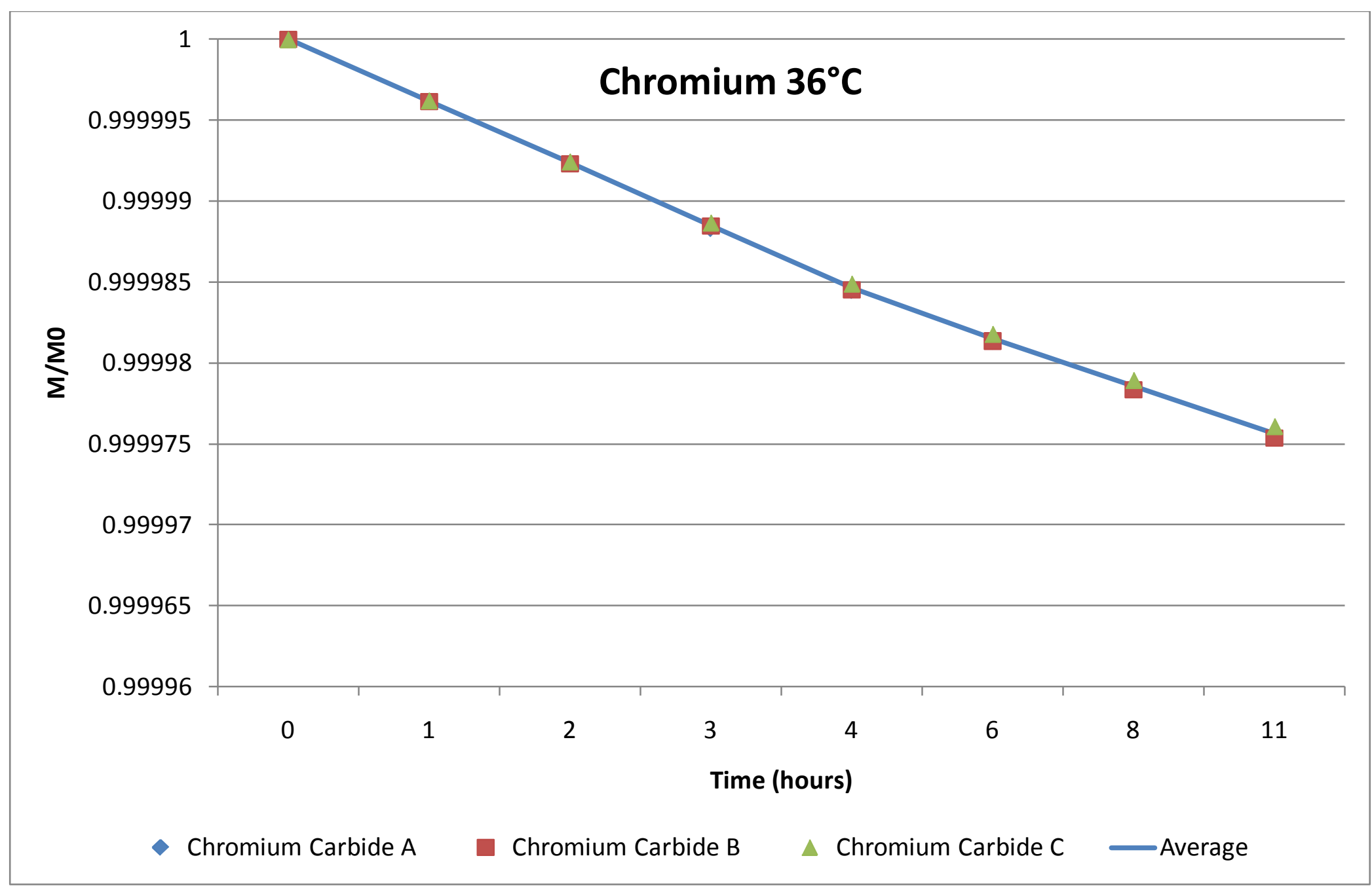




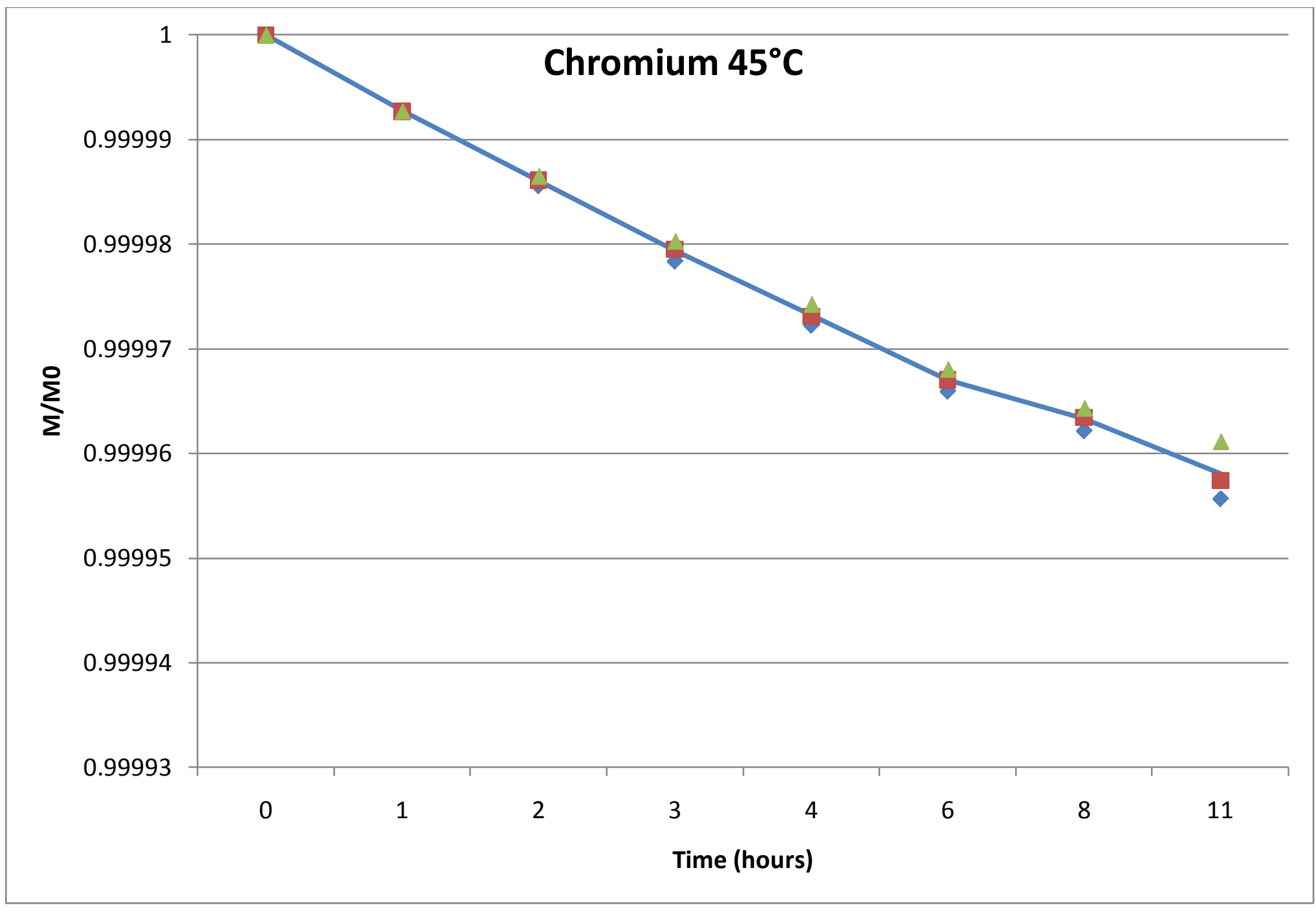




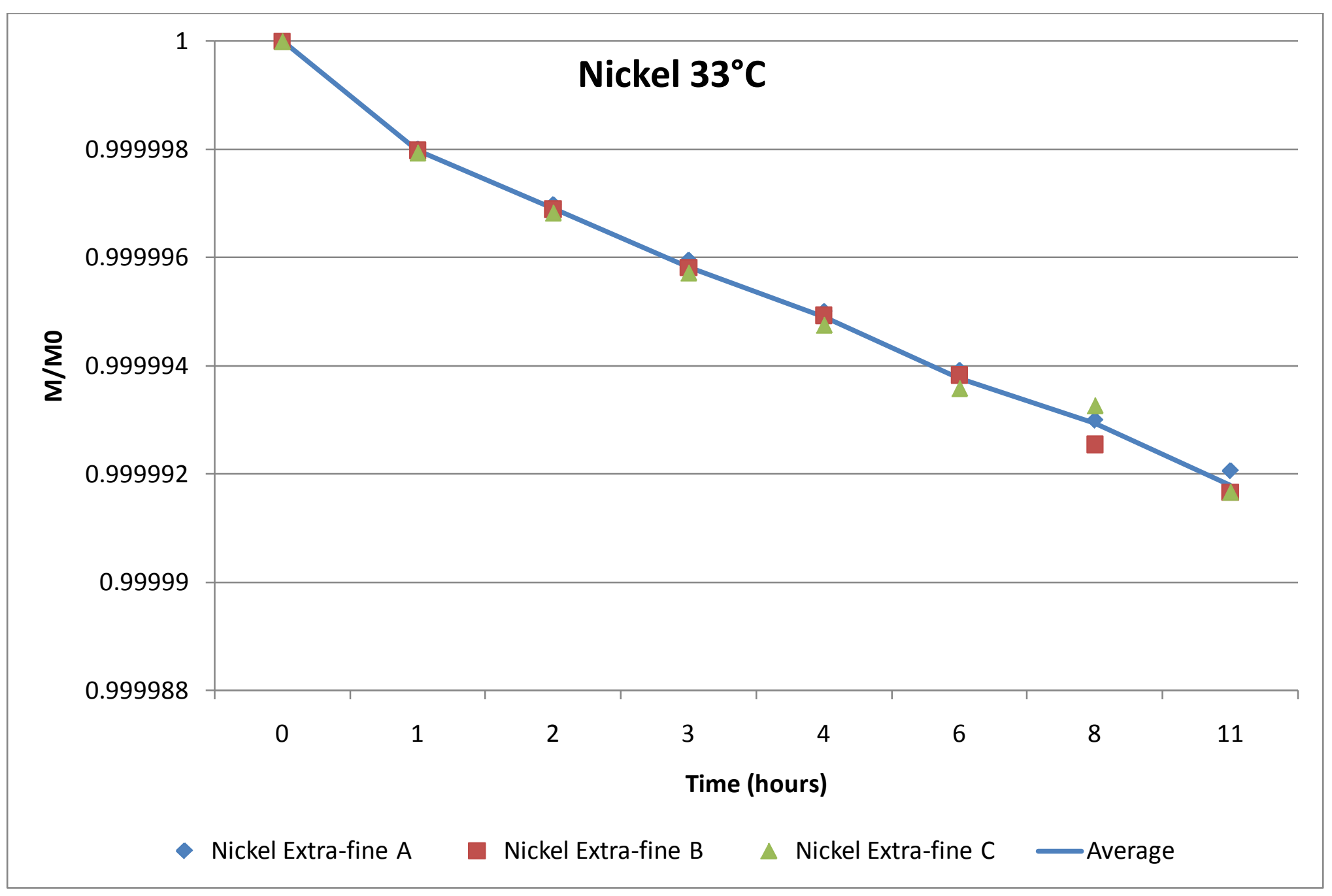




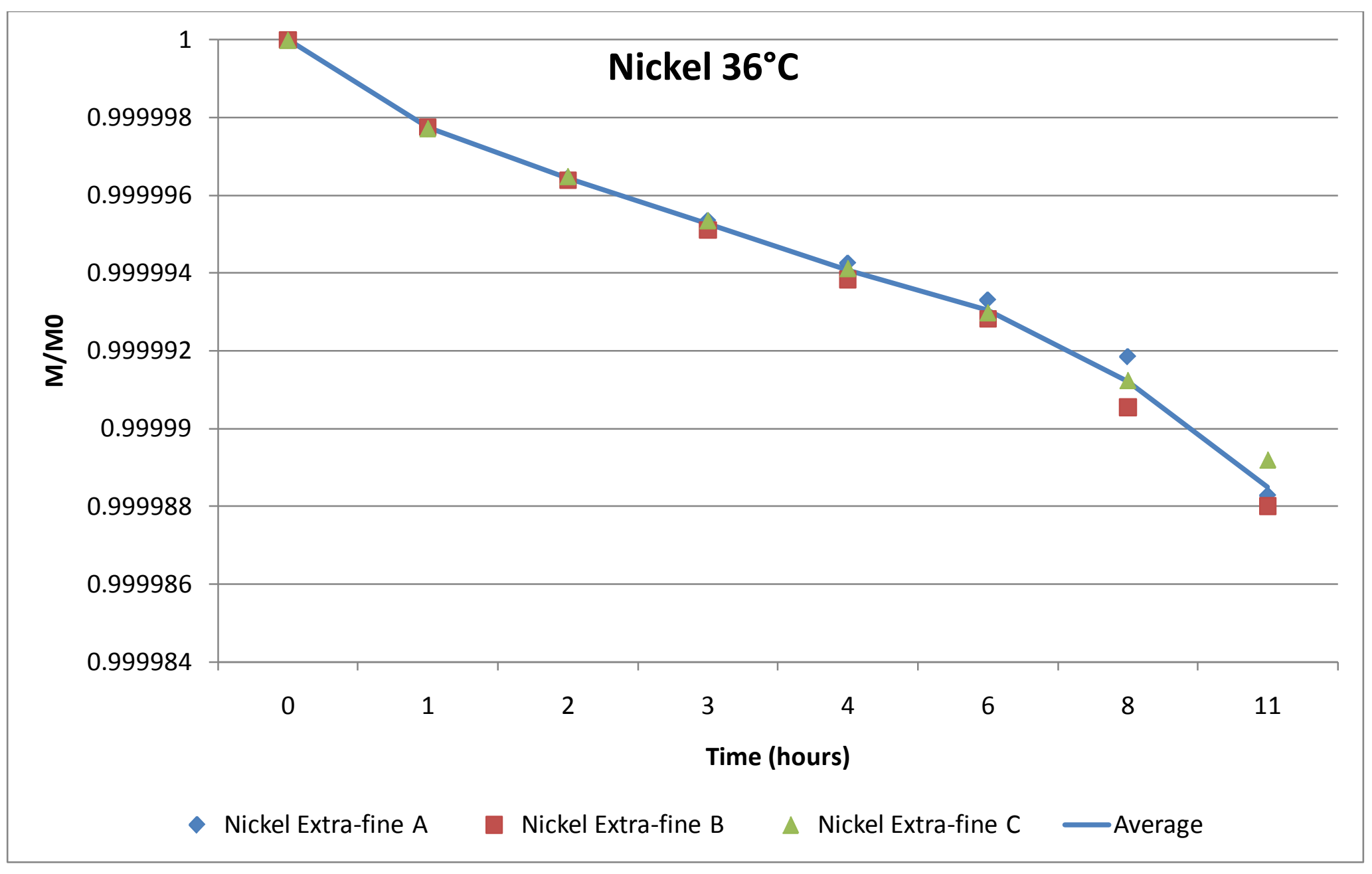




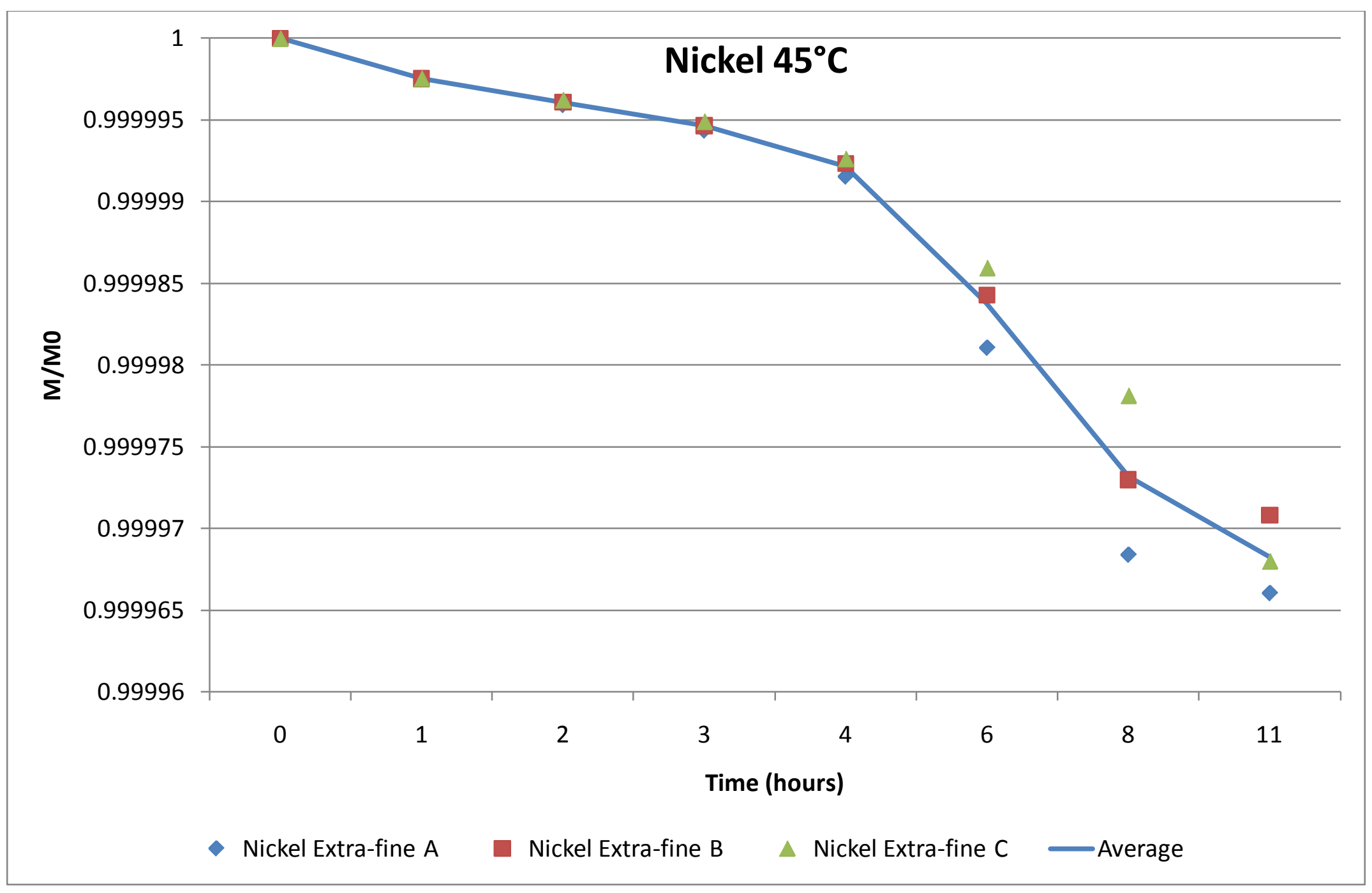

John $\mathrm{H}$.

Hagen 